Historia Slavorum Occidentis

2021, nr $3(30)$

ISSN 2084-1213

DOI: $10.15804 /$ hso2 10308

Jerzy Pysiak (WarszaWa)

ORCID: 0000-0003-4588-4279

\title{
Aleksander Gieysztor i Gerard Labuda jako badacze historii powszechnej
}

Słowa kluczowe: Aleksander Gieysztor (1916-1999), Gerard Labuda (1916-2010), historiografia polska XX w., historia powszechna, średniowiecze

Keywords: Aleksander Gieysztor (1916-1999), Gerard Labuda (1916-2010), Polish historiography of the twentieth century, general history, Middle Ages

\begin{abstract}
In concordance with the scholarly profile of the Warsaw historiographical school of the time, Aleksander Gieysztor's early research, which begun in the 1930s. was devoted to the Carolingian monarchy and the origins of the crusade movement. It was not until after the Second World War that Gieysztor turned his attention to the Slavic studies, conducted from the very beginning by the Poznań historiographical school, to which Gerard Labuda remained faithful throughout his research career. Labuda was primarily interested in Western Slavdom, the origins of Slavic states (Samo's Empire) and the political and legal aspects of the functioning of early states in Central Europe. Aleksander Gieysztor's studies on Slavic Europe focused mainly on early medieval Rus' and on comparative research confronting the phenomena of the history of culture and the history of state and social institutions in Central and Eastern Europe with analogous phenomena and processes known from Carolingian and post-Carolingian Europe.
\end{abstract}

I.

Nie ulega wątpliwości, że głównym przedmiotem zainteresowań badawczych ${ }^{1}$ zarówno

1 W niniejszym artykule pomijam wątek historii gospodarczej, tak wyraźnie obecny w badaniach powszechnodziejowych A. Gieysztora i G. Labudy, został on bowiem bardzo wyczerpująco zaprezentowany w artykule Mariana Dygi zamieszczonym w niniejszym tomie. 
Aleksandra Gieysztora, jak i Gerarda Labudy - w ich dojrzałym życiu naukowym - była historia Polski. Kwestionariusz badawczy dotyczący dziejów rodzimych konstruowany w dziele historiograficznym każdego z obu uczonych pozostawał jednak $\mathrm{w}$ ścisłym powiązaniu z prowadzonymi przez nich badaniami powszechnodziejowymi. Te ostatnie nie stanowily jednak ani dla Labudy, ani dla Gieysztora jedynie pobocznego wątku ich zainteresowań - owszem, były fundamentalnym elementem ich warsztatu badań nad historią średniowiecznej Polski. W podejściu A. Gieysztora i G. Labudy tak do historii powszechnej w ogóle, jak do badań nad Polską średniowieczną w ujęciu powszechnodziejowym dostrzegamy zarówno podobieństwa, jak i wyraźne odmienności - wynikające z różnic w zakładanych przez każdego z nich celach badawczych, lecz również $\mathrm{w}$ drodze naukowej obu tych wielkich historyków wywodzących się z odmiennych środowisk uniwersyteckich - warszawskiego i poznańskiego. Każda z owych szkół historiograficznych, ukształtowanych w ciągu około zaledwie dwóch dekad od odrodzenia polskiego Uniwersytetu Warszawskiego i powstania Uniwersytetu im. Adama Mickiewicza w Poznaniu u zarania niepodległości świadomie inaczej profilowała założenia i cele realizowanych na ich łonie badań historycznych. A. Gieysztor ukształtował się jako mediewista w szkole historii powszechnej średniowiecza wykreowanej w latach dwudziestych i trzydziestych XX w. przez Marcelego Handelsmana (1882-1945), twórcę Seminarium Historii Powszechnej na Wydziale Humanistycznym i w Instytucie Historycznym, nieszczęśliwie i bez merytorycznych przesłanek zlikwidowanym w 2020 r. Na seminarium tym - podobnie jak znaczna część warszawskiej szkoły historycznej fascynującym się historiograficzną tradycją, a także współczesnymi dokonaniami historiografii francuskiej, w szczególności paryskiej, a od lat międzywojennych także strasburskiej - pierwsze swoje prace naukowe pisali, potem publikowali Wanda Moszczeńska, Marian Henryk Serejski i Tadeusz Manteuffel ${ }^{2}$. Seminarium M. Handelsmana nie bez przyczyny zyskało sobie potocznie nazwę „seminarium merowińsko-karolińskiego"3 i z owego właśnie pnia wyrosły pierwsze prace A. Gieysztora. Jak

2 T. Manteuffel, Polityka unifikacyjna Chlotara II, Warszawa 1925; tenże, Stosunki polityczne frankońsko-włoskie w wieku VI, Kraków 1927; tenże, Teorja ustroju feodalnego wedtug Consuetudines Feudorum (XII-XIII w.), Warszawa 1930; W. Moszczeńska, Arystokracja w państwie Franków za dynastji Merowingów, Warszawa 1932; M.H. Serejski, Idea Imperium Romanum $w$ Galii Merowińskiej w VI wieku, Przegl. Hist. 25 (1925), s. 261-314.

3 O seminarium „merowińsko-karolińskim” M. Handelsmana zob. M. Handelsman, Badania szkoły warszawskiej nad wczesnym średniowieczem (tłum. z oryginału niemieckiego opublikowanego w 1938 r.), [w:] tegoż, Średniowiecze polskie i powszechne. Wybór pism, wyd. A. Gieysztor, Warszawa 1966, s. 343-348. Zob. też: R. Michałowski, Tadeusz Manteuffel jako badacz dziejów Franków, Przegl. Hist. 86 (1995), z. 3-4, s. 313-318. 
cała grupa uczniów M. Handelsmana A. Gieysztor rozpoczął badania historyczne od studiów nad historią europejską, czego owocem była opublikowana w roku 1938 praca Wtadza Karola Wielkiego w opinii wspótczesnej ${ }^{4}$. Bez wątpienia seminarium Handelsmana i warszawska szkoła historii powszechnej przez niego wykreowana stanowiły wykwit międzywojennej warszawskiej ambicji bycia jednym z liczących się europejskich - zatem w ówczesnym świecie jedynych liczących się w skali całego globu - ośrodków badań nad historią powszechną epoki średniowiecza. Niezaprzeczalne znaczenie dla jej powstania i - trwale przerwanego przez drugą wojnę światową i jej polityczne konsekwencje dla Europy Środkowej - funkcjonowania miała sięgająca głęboko w wiek XIX (a nawet XVIII) tradycyjna warszawska fascynacją Francją i Paryżem, uznawanym za centrum świata, europejskie centrum intelektualne - a co za tym idzie, także centrum światowej nauki - trwająca do lat osiemdziesiątych XX w. Dlatego właśnie czołowe studia dotyczące wczesnego średniowiecza powstałe na Seminarium Historii Powszechnej M. Handelsmana, w tym pierwsza publikacja naukowa Gieysztora, dotyczyły Królestwa Franków, oglądanego jednak bez wątpienia z francuskiej perspektywy, choć ich autorzy nie lekceważyli bynajmniej prac współczesnych historyków niemieckich, w których doskonale się orientowali. Ambicja włączenia warszawskiego środowiska historyków do światowego nurtu historiografii w latach międzywojennych musiała zatem oznaczać obranie drogi przez Paryż i francuską wizję historii.

Warszawska fascynacja nauką francuską i Paryżem dała o sobie znać także po drugiej wojnie światowej, w szczególności po odwilży roku 1956. W konsekwencji politycznej i intelektualnej izolacji Polski i polskiej nauki od ośrodków zachodnioeuropejskich, wynikającej z poddania Polski zwierzchnictwu ZSRR, i podejmowanych przez władze komunistyczne prób poddania polskiej humanistyki indoktrynacji ideologicznej inspirowanej przez Moskwę, lewicujące środowisko naukowe paryskie (a także włoskie), dostrzegające naukowe pożytki z uczciwego intelektualnie zastosowania metodologii marksistowskiej w dziedzinie nauk historycznych, stało się ponownie dla polskiej nauki historycznej oknem na świat, pozwalającym utrzymać nie tylko kontakt intelektualny z nauką europejską, lecz także zapoznawać ją z wynikami badań w Polsce prowadzonych.

Pierwsze dziesięciolecie badawczej aktywności A. Gieysztora wykazało, pod niewątpliwym wpływem szkoły M. Handelsmana i T. Manteuffla, jego żywe zainteresowanie i wysokie kompetencje w zakresie badań nad historią Europy Zachodniej we wczesnym średniowieczu. Po opublikowaniu, jeszcze przed wojną, studiów nad mo-

4 A. Gieysztor, Wtadza Karola Wielkiego w opinii wspótczesnej, Warszawa 1938. 
narchią karolińską A. Gieysztor zajął się badaniami nad wątkiem genezy idei krucjatowej, których owocem była rozprawa doktorska (powstała na paryskim seminarium Louisa Halphena w roku akademickim 1938/1939, a obroniona w 1942 r. w warunkach konspiracyjnych w prywatnym mieszkaniu jej promotora - Stanisława Kętrzyńskiego (1876-1950) i antydatowana w protokole przez przedwojennego dziekana Wydziału Humanistycznego, prof. Stanisława Wędkiewicza (1888-1963) na rok 1939: Ze studiów nad geneza wypraw krzyżowych. Encyklika Sergiusza IV (1009$-1012)^{5}$. W 1945 r. doktorat ten został zatwierdzony przez odradzający się Uniwersytet Warszawski ${ }^{6}$. Praca ta ma charakter wybitnie źródłoznawczy i - poza erudycyjną znajomością literatury przedmiotu - to na biegłości autora w źródłoznawczej analizie krytycznej dokumentu, w tym literacko-językowej, zasadza się najważniejsza teza publikacji: dowiedzenie, że rzekoma encyklika z lat 1009-1012 jest apokryfem pochodzącym z pierwszych miesięcy 1096 r., a zatem powstałym wkrótce po synodzie w Clermont, który rozpoczął właściwą erę wypraw krzyżowych. Gieysztor pokusił się też o atrybucję środowiska, w którym falsyfikat powstał: jego zdaniem musiało to być benedyktyńskie opactwo w Moissac, za czym przemawia nie tylko pochodzenie kodeksu, w którym wpisano tekst rzekomej encykliki Sergiusza IV, lecz również wiele rozmaitych innych faktów. Konsekracja przez papieża Urbana II wkrótce po synodzie w Clermont ołtarza kościoła opackiego w Moissac oraz charakterystyczne dla duchowości kongregacji kluniackiej (do której opactwo owo należało) zainteresowanie Ziemią Świętą i tamtejszymi miejscami kultu, niezwykle intensywna cześć dla pamiątek Męki i Zmartwychwstania Chrystusa (w tym sprowadzonych z Ziemi Świętej relikwii) widoczna w powstających około 1100 r. w Moissac hymnariuszach i w ikonografii płaskorzeźb z około 1100 r. zdobiących krużganek opactwa, wreszcie bezpośrednie żywe kontakty konwentu z Moissac z patriarchatem jerozolimskim i klerem Bazyliki Grobu Świętego skłoniły A. Gieysztora do wniosku, że w tym właśnie opactwie w 1096 r. - w atmosferze krucjatowego entuzjazmu - sfabrykowano propagandowy, agitacyjny apokryf. Jego autorstwo przypisano papieżowi urzędującemu bezpośrednio po zburzeniu Bazyliki Grobu Świętego na polecenie kalifa Al-Hākima (1009) - to właśnie wydarzenie miało skłonić Sergiusza IV do publikacji encykliki nawołującej chrześcijan do wojny świętej z islamem. Warto dodać,

5 Tenże, Ze studiów nad geneza wypraw krzyżowych. Encyklika Sergiusza IV (1009-1012), Warszawa 1948.

6 M. Koczerska, Aleksander Gieysztor 17 VII 1916-9 II 1999. Szkic biograficzny, Studia Źródłoznawcze 36 (2016), s. 1-12, tu s. 6-7. 
że najbardziej esencjonalną część owej rozprawy A. Gieysztor opublikował wkrótce w prestiżowym brytyjskim czasopiśmie „Mediaevalia et humanistica” 7 .

Metodę analizy krytycznej źródeł i interpretacji, jaką posłużył się A. Gieysztor w studium rzekomej encykliki Sergiusza IV, uznać należy za swoistą - wręcz emblematyczną - dla całej jego postawy badawczej. W pracy tej odnajdujemy niemal wszystkie elementy jego warsztatu badawczego, znane i rozpoznawalne w dorobku Gieysztora w kolejnym półwieczu jego naukowej aktywności. Są to: skrupulatna, drobiazgowa wręcz, wzorcowa źródłoznawczo krytyczna analiza heurystyczna i hermeneutyczna, wsparta na wynikających stąd przesłankach interpretacja źródła; zastosowanie tak szeroko, jak dalece było to zasadne, metody porównawczej; posługiwanie się instrumentarium badawczym nauk o literaturze i danych językoznawczych (badanie składni, ortografii - w tym użycia samogłosek i spółgłosek, stylistyki i leksyki) oraz historyczno-artystycznych i kodykologicznych. A. Gieysztor badane źródło traktował bowiem jako źródło wiedzy nie tylko w zakresie przekazanego przez nie tekstu (treści), lecz również jako fakt historyczny, powstały, wynikający i funkcjonujący w podlegającym poznaniu - poprzez badanie historyczne - otoczeniu historycznym, cywilizacyjnym i społecznym, uznawał zatem, że tak samo owo źródło powinno być badane.

Jest nierozstrzygniętą zagadką historii historiografii, w jaką stronę skierowałyby się badania naukowe Gieysztora w dojrzałym wieku, gdyby nie druga wojna światowa i geopolityczne konsekwencje dla Polski - i polskiej nauki - powstałego po 1945 r. porządku. Siłą politycznych faktów A. Gieysztor został zmuszony do porzucenia od schyłku lat czterdziestych zachodnioeuropejskiej tematyki badawczej: żelazna kurtyna odcięła go, podobnie jak innych polskich historyków, od kontaktu z zachodnimi ośrodkami naukowymi, nie pozwalając na prowadzenie poważnych studiów nad historią europejską. Początkowo zatem z konieczności skupił się na polskim średniowieczu, czemu sprzyjało powołanie w 1949 r. Kierownictwa Badań nad Początkami Państwa Polskiego, na którego czele Gieysztor stał przez kolejne pięć lat, do czasu, gdy funkcje Kierownictwa przejął stworzony w 1953 r. Instytut Historii Kultury Materialnej PAN. Mimo formalnej utraty funkcji kierownika badań, które od owego czasu przyjęło się nazywać milenijnymi, A. Gieysztor pozostał najważniejszym - wraz z Witoldem Henslem (1917-2008) - liderem owego wielkiego projektu badawczego, m.in. jako wicedyrektor IHKM (1953-1955), lecz przede wszyst-

7 A. Gieysztor, The Genesis of the Crusades: The Encyclical of Sergius IV (1009-1012), Medievalia et humanistica. Studies in medieval and Renaissance culture 5 (1948), s. 3-23. 
kim jako mediewista powszechnie darzony naukowym poważaniem, autor jednego z najistotniejszych tekstów programowych badań milenijnych ${ }^{8}$. Zwrot Gieysztora ku badaniom nad początkami państwa polskiego istotny jest nie tylko dlatego, że to wówczas przedłożył on nad pierwotne swoje zainteresowanie historią powszechną średniowiecza historię Polski. W istocie rzeczy już jego habilitacja (1948), poświęcona daninie w owsie w średniowiecznej Polsce, wskazywała na zmianę, jeśli nie zainteresowań badawczych, to co najmniej przedmiotu prowadzonych badań. Owszem, mimo oczywistej fascynacji A. Gieysztora początkami państwa polskiego i jego zaangażowania w prowadzone nad nimi badania, wątki powszechnodziejowe pozostały ważnym elementem jego twórczości naukowej przez kolejne półwiecze. O udziale Gieysztora w projekcie milenijnym piszę dlatego, że jest on świadectwem innych jeszcze zwrotów - metodologicznego i tematycznego - dotąd w jego profilu badawczym nieobecnych, od końca lat czterdziestych trwale przecież wchodzących do warsztatu naukowego A. Gieysztora, to jest włączenia w zakres jego pola badawczego wątków słowianoznawczych i interpretacji wyników badań archeologicznych. Te ostatnie będą obecne w znakomitej większości prac uczonego poświęconych średniowieczu europejskiemu, do końca jego aktywności naukowej.

W badaniach powszechnodziejowych Gieysztora - oczywiście przede wszystkim dotyczących historii Europy średniowiecznej - łatwo jest wyróżnić kilka wątków wiodących. Zamiłowanie do historii państwa Franków, wywodzące się z początków jego kariery naukowej (wspomniane powyżej merowińsko-karolińskie Seminarium Historii Powszechnej Handelsmana) dało raz jeszcze o sobie znać, gdy Gieysztor opatrzył obszernym komentarzem naukowym wydane w serii „Biblioteka Narodowa” Zakładu Narodowego im. Ossolińskich tłumaczenie na język polski Vita Karoli Magni Einharda ${ }^{9}$. Była to uwspółcześniona pod względem stanu badań - co ważniejsze, tym razem zawierająca komentarz zawodowego historyka uniwersyteckiego reedycja tłumaczenia opublikowanego przez Jana Parandowskiego w $1935 \mathrm{r} .^{10} \mathrm{Wraz}$ z ogłoszonym niedługo później artykułem Problem karolińskiej reformy pisma ${ }^{11}$ był

8 Tenże, Polskie Millenium. Z zagadnień wspótpracy historii i archeologii wczesnodziejowej, Przegl. Hist. 38 (1948), s. 391-412. Zob. też: A. Szczerba, Powołanie Kierownictwa Badań nad Początkami Państwa Polskiego, Przegląd Archeologiczny 65 (2017), s. 13-18.

9 Einhard, Życie Karola Wielkiego, przeł. J. Parandowski; wstępem i objaśnieniami opatrzył A. Gieysztor, Wrocław 1950.

10 Einhard, Życie Karola Wielkiego, z oryginału łacińskiego przełożył, wstępem i objaśnieniami zaopatrzył J. Parandowski, Warszawa-Lwów 1935.

11 A. Gieysztor, Problem karolińskiej reformy pisma, Archeologia 5 (1952-1953), s. 155-176. 
to jednak ostatni akcent frankijski w dziełach warszawskiego mediewisty, który do tej tematyki już więcej w swej twórczości nie powracał.

Słowianoznawcze wątki w badaniach powszechnodziejowych Gieysztora pojawiały się w dwóch aspektach: po pierwsze, badań nad pierwotną politeistyczną religią Słowian, której poświęcił nie tylko wzmianki w drobniejszych rozproszonych pracach (także w językach zachodnioeuropejskich) ${ }^{12}$, lecz przede wszystkim monografię, opublikowaną po raz pierwszy, po wieloletnich studiach, w $1982 \mathrm{r}$. w formie popularnonaukowej ${ }^{13}$. Wzbudziła ona uznanie w innych krajach środkowoeuropejskich, czego dowodem są tłumaczenia na języki bułgarski i czeski ${ }^{14}$. Mimo publikacji tej książki na początku lat osiemdziesiątych XX w. A. Gieysztor w ciągu kolejnych lat nadal pracował nad tym tematem, a owocem jego wysiłków było nowe, pośmiertne już, wydanie z rękopisu, z aparatem naukowym, z $2006 \mathrm{r} .{ }^{15} \mathrm{~W}$ pierwszym i drugim wydaniu pracy $(1982,1986)$ wyraźnie dostrzegalne są inspiracje religijno-mitologicznym trójfunkcjonalizmem Georgesa Dumézila ${ }^{16}$. W późniejszej wersji zostały one poddane przez autora krytycznej redukcji. Nie może ulegać wątpliwości, że niezależnie od tego, czy przekonuje nas pierwotna Gieysztorowska trójfunkcyjna interpretacja mitologii i religii wczesnośredniowiecznych Słowian, czy rozczarowu-

12 Problematykę tę A. Gieysztor poruszał w swoich wystąpieniach naukowych i drobniejszych publikacjach już wcześniej: zob. A. Gieysztor, The Slavic Pantheon and new comparative mythology, Quaestiones medii aevi 1 (1976), s. 7-32; tenże, La mythologie slave, le modèle trifonctionnel et la culture populaire, [w:] La Pologne au XV Congrès international des sciences historiques à Bucarest, red. S. Bylina, Wrocław 1980, s. 11-24. Merytoryczna zawartość tych prac została w większości później skonsumowana w Mitologii Słowian - patrz przyp. niżej.

13 Tenże, Mitologia Słowian, Warszawa 1982. Zob. też: tenże, En guise de conclusion: la religion traditionnelle slave et la christianisation de la Rus', changement et continuité, [w:] Proceedings of the International Congress Commemorating the Millennium of the Christianity in Rus' - Ukraine, wyd. O. Pritsak, I. Ševčenko, Harvard Ukrainian Studies 12/13 (1988/1989), s. 870-877.

14 A. Gejŝor, Mitologiâ na Slavânite, prevela ot polski K. Mitova, Sofiâ 1986; tenże, Mytologie Slovanů, přeložila H. Komárková, Praha 2020.

15 A. Gieysztor, Mitologia Słowian, wydanie 3, rozszerzone i zmienione, wstęp K. Modzelewski; posłowie L.P. Słupecki; oprac. na podst. rękopisu A. Pieniądz, Warszawa 2006.

16 Przede wszystkim: G. Dumézil, Les dieux des Germains: essai sur la formation de la religion scandinave, Paris 1959 (wyd. 1); tenże, La Religion romaine archaïque, avec un appendice sur la religion des Étrusques, Paris 1966 (wyd. 1); tenże, Mythe et épopée, t. 1: L'idéologie des trois fonctions dans les épopées des peuples indo-européens, Paris 1968 (wyd. 1); tenże, Les Dieux souverains des Indo-Européens, Paris 1977 (wyd. 1). 
je późniejsze częściowe od niej odejście ${ }^{17}$, w swej Mitologii Słowian A. Gieysztor dokonał jednej z najbardziej kompletnych rekonstrukcji wierzeń - w tym panteonu bóstw i ich funkcji - Słowiańszczyzny wczesnośredniowiecznej. Podstawą owej rekonstrukcji i interpretacji były źródła odnoszące się do ludów Połabia i przede wszystkim wczesnej Rusi, która zajmowała od końca lat pięćdziesiątych szczególnie istotną pozycję w powszechnodziejowych badaniach Gieysztora publikowanych zarówno w Polsce, jak i za granicą.

Przełom roku 1956 w Polsce przyniósł lekkie uniesienie się żelaznej kurtyny, pozwalając polskim naukowcom ponownie nawiązać kontakty z zagranicznymi ośrodkami i środowiskami badawczymi. Dla A. Gieysztora, praktycznego frankofila, szczególnie ważne okazało się otwarcie na Paryż, nawiązanie przyjaźni naukowych z Fernandem Braudelem i Jacques'em Le Goffem, za ich zaś pośrednictwem także z uczonymi włoskimi, w szczególności skupionymi wokół założonego w 1952 r. Centro italiano di Studi sull'alto medioevo w Spoleto. W pracach dorocznych konferencji (Settimane di studio) w Spoleto Gieysztor brał udział regularnie przez kolejne dziesięciolecia, włączając do tego środowiska swoich uczniów i współpracowników. Nie było to bez znaczenia dla kierunków rozwoju jego badań powszechnodziejowych, bowiem mediewistów francuskich i włoskich zajmujących się wczesnym średniowieczem niezmiernie interesowała wczesnośredniowieczna Słowiańszczyzna, ze szczególnym uwzględnieniem Rusi i możliwość prowadzenia badań komparatystycznych. Na drogę tę, co logicznie wynikało także z zaangażowania w program badań milenijnych, wstąpił również A. Gieysztor. Już w 1958 r., w tomie jubileuszowym Henryka Łowmiańskiego, ogłosił artykuł $Z$ zagadnień kultury staroruskiej: składniki rodzime i obce $e^{18}$. Autor deklaruje w nim, że będą go interesować przede wszystkim wybrane zjawiska kultury duchowej „nie dlatego, aby wystarczały one dla zrozumienia całokształtu życia społeczeństwa staroruskiego, ale głównie dlatego, że mają one wartość soczewki skupiającej także wiele innych problemów kultury, zarówno

\footnotetext{
17 Zgodnie z treścią rozmów, jakie w 1997 r. przeprowadziłem z wybitnym francuskim mediewistą, profesorem Bernardem Guenée (1927-2010), wówczas emerytowanym profesorem Sorbony, sceptyczne stanowisko do zastosowania schematu trójfunkcyjnego do analizy i rekonstrukcji religii i mitologii słowiańskiej (zaprezentowanego przez A. Gieysztora podczas jego paryskich wykładów zorganizowanych przez Ośrodek Kultury Polskiej na Université Paris IV w latach osiemdziesiątych XX w.) zajął twórca tej koncepcji, Georges Dumézil. Nie ułatwiło to niestety recepcji tez Gieysztora we francuskim środowisku naukowym.

18 A. Gieysztor, $Z$ zagadnień kultury staroruskiej: składniki rodzime i obce, [w:] Studia historica $w$ 35-lecie pracy naukowej Henryka Łowmiańskiego, red. A. Gieysztor i in., Warszawa 1958, s. 73-89.
} 
z dziedziny materialnych warunków bytu, jak organizacji i instytucji społecznych"19. Deklaracja ta może być uznana za emblematyczną dla całokształtu badań powszechnodziejowych A. Gieysztora i dlatego ją tu przytaczam. Jego prace dotyczące historii powszechnej powstałe po doktoracie były w większości drobne, lecz ich autor bardzo precyzyjnie wybierał problem poznawczy, a kwestionariusz badawczy konstruował właśnie według sformułowanej w powyżej cytowanym zdaniu zasady. Badane kwestie, by były interesujące dla A. Gieysztora, musiały dawać możliwość wielowątkowej analizy i interpretacji, w szczególności dzięki wykorzystaniu metody porównawczej. W Zagadnieniach kultury staroruskiej autor mierzy się z ryzykownym zadaniem: pogodzenia rzetelnego stanu wiedzy na temat państwowości, społeczeństwa i kultury staroruskiej oraz wpływu czynników obcych - przede wszystkim skandynawskich, lecz również ugrofińskich, chazarskich, ludów tureckich - na rodzimy żywioł wschodniosłowiański i ich rolę w genezie wczesnośredniowiecznego państwa i cywilizacji ruskiej, z dominującą ideologicznie w nauce radzieckiej - starającej się wywierać wpływ na publikacje na ten temat ukazujące się w państwach bloku wschodniego - narracją historiograficzną negującą kluczową rolę Waregów w powstaniu Rusi Kijowskiej jako państwa, społeczeństwa i kultury. Z zadania tego A. Gieysztor wybrnął znakomicie, z jednej strony deklaratywnie potwierdzając rodzime podłoże i charakter państwowości i kultury staroruskiej, z drugiej jednak ukazując wszystkie czynniki niesłowiańskie, bez których udziału w procesie tworzenia państwa i społeczeństwa nie sposób sobie wyobrazić wczesnośredniowiecznej Rusi.

W artykule tym A. Gieysztor uwypuklił względne (zwłaszcza w porównaniu z państwami Słowian zachodnich) bogactwo źródeł pisanych, które pozwalają rekonstruować tworzenie się pierwszych organizmów politycznych, budowy Rusi jako państwa, krzepnięcia jej podstaw ustrojowych i terytorialnych oraz zachodzących wśród ludności przemian kulturowych. Kolejny raz ujawniła się wrażliwość językoznawcza uczonego: traktowanie przez niego zabytków dawnego języka jako niezwykle ważnej sfery poznania historycznego. Poza istotną kwestią zapożyczenia przez Ruś bizantyńskiej kultury intelektualnej i duchowej - za pośrednictwem bułgarskim - położono silny nacisk na wpływ olśniewającej w X stuleciu cywilizacji Carstwa Bułgarskiego, również na decyzje o przebiegu i kształcie chrystianizacji Rusi, jak też powstanie i kształt staroruskiego języka liturgicznego i literackiego. Jednocześnie uczony wskazywał na obszary, w jakich najsilniejszy wpływ miały niesłowiańskie 
i niegreckie zapożyczenia językowe: nordyckie, tureckie, ugrofińskie. Powołując się na badania czołowych polskich filologów słowiańskich (Tadeusz Lehr-Spławiński), konkludował że „podstawowy zasób leksykalny był tak bogaty już w najwcześniejszym średniowieczu, że wystarczał Słowianom dla określenia zjawisk zarówno zewnętrznych, przyrody, kultury materialnej, stosunków pokrewieństwa i innych stosunków społecznych, różnych dziedzin produkcji, wojskowości, jak też przeżyć psychicznych i wcale licznych pojęć abstrakcyjnych”. Oprócz źródeł pisanych wziął pod uwagę także archeologiczne - dotyczące nie tylko kultury materialnej, jak przykładowo ewolucja struktury osadniczej i domów mieszkalnych między IX a X w., lecz i duchowej, jak listy pisane na korze brzozowej. Zajął się także wątkiem pierwotnej religii ruskiej, opowiadając się za istnieniem obszernego panteonu bóstw czczonych przez dawnych Rusów i nie wykluczając, że w ich katalogu znalazły się bóstwa pochodzenia obcego, zatem niesłowiańskiego.

Omawiany artykuł, choć relatywnie krótki, należy uznawać za jeden z ważniejszych w dorobku A. Gieysztora w dziedzinie jego badań powszechnodziejowych. $\mathrm{Z}$ jednej strony stanowił on zwięzłą, a przecież ważką poznawczo, analizę i interpretację najstarszej cywilizacji dawnej Rusi, z drugiej zaś był punktem wyjścia do jego dalszych studiów nad mitologią słowiańską, w których, jak wspomniałem, szczególny nacisk, poza religią Połabian i Pomorzan, kładł on na rekonstrukcję wierzeń staroruskich. Zawarte w owym tekście tezy modyfikował w kolejnych publikacjach poświęconych tej tematyce w ciągu kolejnych 40 lat twórczości tylko w niewielkim stopniu, przede wszystkim aktualizując stan badań i dodając nowe wątki. W badaniach dotyczących wczesnośredniowiecznej Słowiańszczyzny Ruś zajmowała bez wątpienia miejsce uprzywilejowane, czego dowodem jest choćby La strutturazione culturale dei paesi slavi nell alto medioevo z 1964 r., w której Gieysztor powtarza wszystkie zasadnicze tezy znane z Zagadnień kultury staroruskiej. Choć tytuł artykułu mówi, że jest on poświęcony Słowiańszczyźnie w ogólności, to jego zasadnicze jądro naukowe dotyczy Rusi. Jedynie część wstępna przybliża zachodnioeuropejskiemu audytorium zagadnienia pojawienia się Słowian w Europie i etnogenezy trzech głównych grup językowych Słowian na podstawie danych językoznawczych i archeologicznych. W zakończeniu tekstu A. Gieysztor komparatystycznie konfrontuje stawiane w artykule pytania badawcze dotyczące asymilacji kultury bizantyńskiej i nordyckiej na Rusi oraz najważniejsze płynące z nich wnioski z procesem przyjmowania cywilizacji łacińskiej w państwach Europy Środkowej - w Czechach, Polsce i na Węgrzech. Wątek ten nie doczekał się jednak w cytowanym artykule znaczącego 
merytorycznie rozwinięcia ${ }^{20}$. O tym, że kwestie kultury duchowej wczesnośredniowiecznej Rusi zajmowały w myśli historiograficznej A. Gieysztora uprzywilejowane miejsce, świadczy najlepiej treść jego wykładu, wygłoszonego podczas uroczystości nadania mu przez Uniwersytet im. Adama Mickiewicza w Poznaniu stopnia doktora honoris causa w roku 1990, poświęconego w głównej mierze politeistycznym wierzeniom na przedchrześcijańskiej Rusi i ruskiej mitologii politeistycznej ${ }^{21}$.

Inną gałęzią powszechnodziejowych poszukiwań uczonego były badania porównawcze, konfrontujące rzeczywistość średniowiecznej Polski z podobnymi zjawiskami i faktami historycznymi w dziejach Europy lub świata. Należy tu wymienić kilka mniejszych, lecz poznawczo ważnych artykułów Gieysztora powstałych w latach sześćdziesiątych, siedemdziesiątych i dziewięćdziesiątych: $W$ sprawie początków trójpolówki w Polsce i krajach sąsiednich (1960) ${ }^{22}$; Kasztelanowie flandryjscy i polscy $(1965)^{23}$, Urząd wojewodziński we wczesnych państwach stowiańskich w IX-XI wieku $(1971)^{24}$ i Historical similarities of Poland and Korea (1994) ${ }^{25}$. O ile pisząc o wprowadzeniu w Polsce trójpolówki na tle podobnego zjawiska w państwach Europy Środkowej oraz o funkcji urzędu wojewody w Polsce, Czechach, na Rusi i na Węgrzech (mistrzowsko posługując się metodą porównawczą) Gieysztor - nie pomijając żadnych różnic wynikających z odmienności tradycji i struktury państwowej obszarów podlegających także, w różnym stopniu, wpływom obcym - ukazywał zasadniczą jedność regionu historyczno-kulturowego Europy Środkowo-Wschodniej przejawiającą się w analogicznych instytucjach państwowych, o tyle badając porównawczo instytucję kasztelanii w Polsce i we Flandrii, dowodził istnienia podobieństw w organizacji władzy terytorialnej na rubieżach - zachodnich lub wschodnich -

20 A. Gieysztor, La strutturazione culturale dei paesi slavi nell alto medioevo, [w:] Centri e vie di irradiazione della civiltà nell'alto medioevo, Settimane di studio del Centro Italiano di studi sull'alto medioevo 11, Spoleto 18-23 aprile 1963, Spoleto 1964, s. 371-392.

21 Tenże, Stowiańska wizja świata, [w:] Alexander Gieysztor. Doctor honoris causa Universitatis Studiorum Mickiewicziane Poznaniensis, Poznan 1990, s. 29-40.

22 Tenże, $W$ sprawie początków trójpolówki $w$ Polsce i krajach sąsiednich, [w: Prace $z$ dziejów Polski feudalnej: ofiarowane Romanowi Grodeckiemu w 70 rocznicę urodzin, red. Z. Kozłowska-Budkowa i in., Warszawa 1960, s. 71-79.

23 Tenże, Kasztelanowie flandryjscy i polscy. Zagadnienia porównawcze, Studia historyczne 7 (1965), s. 97-107.

24 Tenże, Urzą wojewodziński we wczesnych państwach stowiańskich w IX-XI wieku, Archeologia Polski 16 (1971), s. 317-325.

25 Tenże, Historical similarities of Poland and Korea, Korea Observer 25 (1994), z. 3, s. 421-428 . 
średniowiecznego Cesarstwa. Tym samym przekonująco pokazywał przynależność Polski i jej uczestnictwo w strukturach średniowiecznej Europy postkarolińskiej i instytucjonalne wysiłki monarchii piastowskiej - jednej z peryferii ówczesnego świata łacińskiego - w dążeniu do unowocześnienia przez asymilację wzorców stosowanych w ówczesnej metropolii cywilizacyjnej. Nieco mniej przekonujące było poszukiwanie podobieństw między dziejami Korei i Polski, lecz niektóre odnalezione przez Gieysztora analogie w historii obu krajów są frapujące. Niezależnie jednak od dyskusyjności niektórych tez pomieszczonych w cytowanym artykule uczony dał w nim dowód wielkiej wrażliwości na rodzące się nurty w światowej historiografii. Historia porównawcza Polski i Korei, wymagająca przecież znaczącego pogłębienia analitycznego i metodologicznego, stanowiła jedną z nielicznych w polskiej historiografii schyłku XX stulecia odpowiedzi na pojawiające się wówczas w historiografii światowej postulaty uprawiania historii globalnej.

W tym samym nurcie badań porównawczych mieści się artykuł A. Gieysztora o herezji lub apostazji w zachodniej i środkowej Europie ${ }^{26}$. Ponownie mamy tu do czynienia z bardzo konsekwentnie zastosowaną metodą porównawczą, mimo że wnioski przyjęte przez badacza w tej niezwykle interesującej pracy wydają mi się częściowo chybione, co stanowi konsekwencję nielogicznie zrealizowanego założenia teoretycznego. Główną tezą Gieysztora w cytowanym artykule jest bowiem - pod nieobecność w Polsce i w Europie Środkowej przed wiekiem XIV znaczących ruchów heretyckich (a i w stuleciu następnym, poza husytyzmem, trudno uznać nasz region za szczególnie płodny pod względem refleksji religijnej, w tym także nieortodoksyjnej) - funkcjonalna analogia między zachodnioeuropejską herezją a środkowo- i wschodnioeuropejską apostazją, rozumianą jako porzucenie wiary chrześcijańskiej i powrót do wierzeń pierwotnych. Jak najsłuszniejsza może być bowiem teza A. Gieysztora, że pojawienie się w społeczeństwie średniowiecznym masowych ruchów heretyckich - zatem takich, które (w odróżnieniu od herezji adopcjańskiej w VIII-IX w. czy orleańskiej w stuleciu XI) nie były wynikiem spekulacji teologicznej nurtującej niewielką elitarną grupę duchowieństwa, lecz stały się intelektualnie i religijnie przekonujące dla szerokich grup społecznych rycerstwa, mieszczaństwa czy bogatego chłopstwa (jak w przypadku waldensów czy katarów) - przypada na moment, „gdy ewangelizacja wsi dobiegała końca lub od niedawna była zamknięta”. Niemniej wyklucza ona jednak poprawność stwierdzenia o funk-

26 Tenże, Uwagi o funkcjach społecznych apostazji i herezji $w$ Europie wczesnośredniowiecznej, [w:] Z polskich studiów slawistycznych, seria 2: Historia, Warszawa 1963, s. 53-60. 
cjonalnej analogii społecznej reakcji pogańskiej w jedenastowiecznej Polsce czy na Rusi z zachodnioeuropejskimi ruchami heretyckimi.

Trzecim nurtem powszechnodziejowych badań A. Gieysztora są intelektualne poszukiwania związane z miejscem Polski w średniowiecznej cywilizacji europejskiej. Była to kwestia zajmująca uczonego przez co najmniej 40 ostatnich lat jego aktywności naukowej, zawsze budząca żywe zainteresowanie naukowych gremiów zachodnioeuropejskich i polskich, stanowiących jego główne audytorium. Prace, jakie trzeba w tym miejscu przywołać, dotyczyły dziedzictwa kulturowego i artystycznego starożytności rzymskiej i barbarzyńskiej na ziemiach polskich w średniowieczu $^{27}$, cywilizacyjnego miejsca Polski i Europy Środkowo-Wschodniej między Zachodem i Wschodem średniowiecznej Europy ${ }^{28}$, wreszcie poznawania peryferyjnego regionu Europy Środkowo-Wschodniej przez przedstawicieli cywilizacyjnej metropolii śródziemnomorskiej w późnym średniowieczu ${ }^{29}$. Ogromnie istotnym aspektem tego wątku badań A. Gieysztora były analiza i rekonstrukcja procesu akulturacji tworzących się państw i społeczeństw Europy Środkowo-Wschodniej w X-XI w. oraz powstawanie ich insty tucji w procesie wymiany cywilizacyjnej i interakcji kulturowej i politycznej z Europą postkarolińską, w znacznym stopniu - co wynika z charakteru zachowanych dla tej epoki źródeł - dotyczących historii Kościoła, uprawianej jednak jak historia społeczna. Wśród prac poświęconych tej tematyce publikowanych w językach zachodnioeuropejskich wskazać należy przede wszystkim kilka niezwykle esencjonalnych publikacji. Pierwszą z nich jest bez wątpienia Christiana Respublica et la politique orientale de l'Empire ${ }^{30}$, w którym początki państwa

27 Tenże, L'héritage artistique de l'antiquité barbare et romaine sur le territoire de la Pologne, [w: Mélanges d'art et d'histoire. Mélanges offertes à René Crozet à l'occasion de son $70^{\text {ème }}$ anniversaire, par ses amis, ses collèques, ses élèves, éd. P. Gallais, Y.F. Riou, Poitiers 1966, s. $23-$ -31 .

28 Tenże, La Polonia medioevale tra Occidente ed Oriente, Studi storici 9, z. 2 (aprile-giugno 1968), s. 247-260; tenże, Early Medieval Poland and Europe, [w:] Nation, church, culture, red. A. Chruszczewski, Lublin 1990, s. 7-26; tenże, L'Europe médiévale du Centre-est: frontières mouvantes de cultures, [w:] Europa medioevale e mondo bizantino. Contatti effettivi e possibilità di studi comparati (Tavola ronda del XVIII Congresso del CISH - Montréal, 29 agosto 1995), red. G. Arnaldi, G. Cavallo, Roma 1997, s. 213-220; tenże, L'Europe nouvelle autour de l'An Mil. La Papauté, l'Empire et les „nouveaux venus”, Roma 1997, s. 19-41.

29 Tenże, Le Centre et l'Est européen au XIVe siècle vus de la Méditerannée, [w:] Mélanges en l'honneur de Fernand Braudel, t. 1: Histoire économique du monde méditerranéen 1450-1650, éd. E. Labrousse i in., Toulouse 1973, s. 219-225.

30 Tenże, Christiana Respublica et la politique orientale de l'Empire, [w:] „Renovatio im- 
pierwszych Piastów zostały ukazane w perspektywie geopolitycznej i ideowej odrodzonego za Ottonów Cesarstwa zachodniego w drugiej połowie $\mathrm{X}$ i na przełomie $\mathrm{X}$ i XI w. Z kolei Le fonctionnement des institutions ecclésiastiques rurales en Bohême, en Pologne et en Hongrie aux $X^{e}$ et XI siècles to artykul, w którym Gieysztor, nie porzucając bynajmniej perspektywy europejskiej, starał się zrekonstruować - w sposób, który dziś zostałby przez niektórych uznany być może za zbyt optymistyczny poznawczo, lecz niewątpliwie wciąż niezwykle inspirujący - powstawanie i funkcjonowanie instytucji Kościoła w świeżo ewangelizowanych państwach i społeczeństwach Europy Środkowo-Wschodniej na poziomie lokalnym, wiejskim ${ }^{31}$. Trzecim $\mathrm{z}$ owych studiów jest Sylvestre II et les églises de Pologne et Hongrie ${ }^{32}$, w nowy sposób wprowadzające do historiografii polskiej postać papieża pierwszego millennium, Gerberta z Aurillac, podobnie jak Christiana Respublica, ukazujące funkcjonowanie środkowoeuropejskiego Kościoła około roku 1000 w perspektywie ogólnoeuropejskiej. Nie sposób w tym miejscu pominąć faktu, że owe badania stały się inspiracją dla kolejnego pokolenia polskich mediewistów: mamy tu na myśli w szczególności prace ucznia Gieysztora, Romana Michałowskiego, koncentrujące się na religijnych i ideowych podstawach funkcjonowania państwa, społeczeństwa i Kościoła w Polsce i - w mniejszym stopniu niż było to w przypadku badań Gieysztora - w Europie Środkowo-Wschodniej, będących konsekwencją interakcji monarchii pierwszych Piastów z Europą Zachodnią ${ }^{33}$.

perii". Atti della giornata internazionale di studio per il millenario (Ravenna, 4-5 novembre 1961), Faenza 1963, s. 41-62.

31 Tenże, Le fonctionnement des institutions ecclésiastiques rurales en Bohême, en Pologne et en Hongrie aux $\mathrm{X}^{e}$ et $\mathrm{XI}^{e}$ siècles, [w:] Cristianizzazione ed organizzazione ecclesiastica delle campagne nell'alto medioevo. Espansione e resistenze, Spoleto 1981, cz. 2, s. 925-954.

32 Tenże, Sylvestre II et les églises de Pologne et Hongrie, [w:] Gerberto. Scienza, storia e mito. Atti del Gerberti Symposium (Bobbio 25-27 luglio 1983), red. M. Tosi, Bobbio 1985, s. 733-746.

33 Nie miejsce tu na przytaczanie wszystkich znakomitych studiów R. Michałowskiego poświęconych tej problematyce. Nie sposób jednak omieszkać przytoczyć prace takie, jak: R. Michałowski, Aix-la-Chapelle et Cracovie au XIe siècle, Bullettino dell'Istituto storico italiano per il medio evo 95 (1989) s. 45-69; tenże, Adalbert, Sylvestre II et l'Église de Pologne, [w:] Gerberto d'Aurillac, da abate di Bobbio a papa dell'anno 1000. Atti del congresso internazionale, Bobbio, Auditorium di S. Chiara, 28-30 settembre 2000, red. F. Nuvolone, Bobbio 2001, s. 483-516; tenże, Zjazd gnieźnieński: Religijne przesłanki powstania arcybiskupstwa gnieźnieńskiego, Wrocław 2005; tenże, The Gniezno Summit: the religious premises of the founding of the Archbishopric of Gniezno, przel. A. Kijak, Leiden 2016 (wersja angielskojęzyczna poprzedniej publikacji); tenże, La naissance des églises en Bohême, Pologne et Hongrie aux IX-XI' siècles: 
Pracą A. Gieysztora o ogromnym znaczeniu w dziedzinie badań nad historią powszechną jest Zarys dziejów pisma łacińskiego, książka stanowiąca owoc jego długoletnich zainteresowań językiem pisanym i mówionym jako zjawiskiem historycznym, a także naukami pomocniczymi historii (jednym z głównych wątków książki są badania nad dawnym pismem - paleografia), widzianymi przez Gieysztora jako integralna część instrumentarium badawczego historyka ${ }^{34}$. Pierwszą, ogromnie ważną publikacją uczonego poświęconą pismu lacińskiemu jako zjawisku historyczno-kulturowemu był artykuł poświęcony karolińskiej reformie pisma ${ }^{35}$, którego główne ustalenia zostały później zaktualizowane i skonsumowane w Zarysie dziejów pisma łacińskiego. Książka ta jest syntezą ukazującą genezę, rozwój i funkcjonowanie od Vw. p.n.e do XX w. alfabetycznego pisma łacińskiego w ogromnie szerokim porównawczym kontekście kulturowym: od zarania pisma jako zjawiska cywilizacyjnego, przez starożytne systemy pisma Bliskiego Wschodu, Egiptu i Ameryki prekolumbijskiej. Lwią część swego zainteresowania skoncentrował tu na piśmie łacińskim jako nośniku języka łacińskiego w starożytności, średniowieczu i wczesnej nowożytności, nie omieszkał jednak poświęcić uwagi także europejskim językom narodowym, których alfabetyzacja oparła się na piśmie łacińskim. Bez wątpienia Zarys dziejów pisma łacińskiego to praca mająca charakter zarówno podręcznika akademickiego, jak i niezwykle cennej poznawczo syntezy z zakresu historii kultury i historii społecznej. Pismo łacińskie w dawnej cywilizacji europejskiej, w jego różnych formach - nade wszystko zachowanych w zabytkach kultury materialnej - A. Gieysztor ukazuje jako fakt historyczny czy raczej zbiór takich faktów w ujęciu diachronicznym i synchronicznym. $Z$ jednej strony są one świadectwem kultury i cywilizacyjnego rozwoju europejskich społeczeństw, w których pismo funkcjonowało, z drugiej zaś - jednym z czynników wpływających dynamicznie na rozwój społeczeństwa i jego kultury. Nie ulega wątpliwości, że Zarys dziejów pisma łacińskiego jest jedną z najwybitniejszych w Polsce powojennej prac rekonstruujących kulturę dawnych społeczeństw europejkkich przez pryzmat zjawiska należącego zarazem do sfery kultury duchowej, jak i materialnej. Na oba te aspekty A. Gieysztor zwrócił uwagę czytelnika, przedstawiając dzieje pisma łacińskiego w dawnej Europie: zają się zarówno krojem liter, alfabety-

l'apport de l'Empire, l'apport de la papauté et les caractères spéciaux des églises locales, [w:] Chiese locali e chiese regionali nell'alto medioevo (Spoleto, 4-9 Aprile 2013), 2, Spoleto 2014, s. 1159-1192.

34 A. Gieysztor, Zarys dziejów pisma łacińskiego, Warszawa 1973 (wyd. 2: Warszawa 2009).

35 Tenże, Problem karolińskiej reformy pisma. 
zacją - a zatem poziomem literackości społeczeństw, w których pismo łacińskie na przestrzeni ponad dwóch tysiącleci funkcjonowało - jak i związanymi z piśmiennością aspektami historii kultury materialnej: materiałem pisarskim i obiegiem zabytków piśmienniczych w Europie od czasów starożytnych po nowoczesność.

\section{II.}

Na tym tle droga naukowa G. Labudy odznacza się wyraźną odmiennością i konsekwencją, będącą, powtórzmy, wynikiem ukształtowania jego postawy badawczej jako historyka na Uniwersytecie im. Adama Mickiewicza w Poznaniu. Już pierwsza praca naukowa Labudy - zaginiona podczas drugiej wojny światowej rozprawa doktorska, gotowa w roku 1939, a dotycząca kontaktów wczesnego państwa Piastów ze Skandynawią, przygotowana pod kierunkiem Kazimierza Tymienieckiego (jednego z najważniejszych twórców polskiej historiograficznej szkoły słowianoznawczej) trwale wytyczyła zakres zainteresowań badawczych G. Labudy, którego naukowym celem stała się rekonstrukcja początków Polski w kontekście europejskim, a co za tym logicznie następuje - ogólnosłowiańskim i szerzej: środkowo-i północnoeuropejskim.

Słowianoznawstwo, rozumiane jako studia nad genezą państwa polskiego w najszerzej pojmowanym ujęciu historyczno-kulturowym Europy Środkowo-Wschodniej i Północnej - a zatem w ujęciu porównawczym, uwzględniające - jako niezbędny dla poprawnego zrozumienia badanych procesów i zjawisk - kontekst powstawania wczesnych organizacji państwowych Słowian, w szczególności zachodnich, lecz i południowych, wiodącym kierunkiem badawczym poznańskiej szkoły historycznej stało się nade wszystko dzięki pracy naukowej i dydaktycznej Kazimierza Tymienieckiego (1887-1968), Józefa Widajewicza (1889-1954) i last but not least Józefa Kostrzewskiego (1885-1969). Uczeni ci, jako profesorowie historii lub archeologii Uniwersytetu Poznańskiego, stanęli na sui generis froncie historiograficznej „zimnej wojny” polsko-niemieckiej, zapoczątkowanej jeszcze w wieku XIX i trwającej w niektórych środowiskach do drugiej połowy XX w., której przedmiotem było dowiedzenie lub zaprzeczenie wyższości cywilizacyjnej Germanów wobec Słowian. Jej najdobitniejszym wyrazem była propagowana w niektórych niemieckich środowiskach uniwersyteckich teza o genetycznej niezdolności Słowian do samodzielnego stworzenia państwa i społeczeństwa: wczesnośredniowieczne monarchie słowiańskie powstały rzekomo jedynie w konsekwencji politycznego udziału w tym procesie żywiołu germańskiego - czy to pochodzącego ze Skandynawii, czy to z Germanii kontynentalnej, zatem z „Niemiec”. 
Owi trzej wybitni współtwórcy mediewistycznej szkoły poznańskiej wywarli ogromny wpływ na profil zainteresowań naukowych G. Labudy, któremu pozostał wierny do końca aktywności naukowej. Archeologiczne zainteresowania najważniejszego z uniwersyteckich mistrzów Labudy, K. Tymienieckiego, i naukowe kontakty z J. Kostrzewskim, nawiązane jeszcze w okresie drugiej wojny światowej, odcisnęly niezatarte piętno na jego warsztacie naukowym, prowadząc do wykształcenia się w jego postawie badawczej wielkiej „wrażliwości archeologicznej”, którą wyraźnie w latach powojennych dostrzegamy również $\mathrm{w}$ warsztacie i kwestionariuszu badawczym A. Gieysztora. W pracach poświęconych początkowi państw słowiańskich - czy to państwu Samona, czy monarchii Piastów - G. Labuda nigdy nie omieszkał posiłkować się danymi zaczerpniętymi z dostępnych mu współczesnych badań archeologicznych. Wspomniany zaś powyżej frankocentryzm szkoły warszawskiej, w którego duchu wyrósł i do końca swoich dni pozostawał A. Gieysztor, był - do pewnego stopnia - także udziałem G. Labudy, choć w o wiele mniejszym stopniu. Większość najważniejszych jego prac naukowych ma streszczenia w języku francuskim, choć - w odróżnieniu od A. Gieysztora - G. Labuda nie okazał się wrażliwy na powojenne nowe prądy we francuskiej historiografii czy ogólniej humanistyce, pozostając wierny dawnej, wspólnej dla szkoły niemieckiej i tradycyjnej szkoły francuskiej, metodzie historyczno-krytycznej. G. Labuda znakomicie znał dawniejszą i współczesną sobie historiografię niemiecką i nie tylko doskonale panował nad jej dorobkiem, lecz także aktywnie uczestniczył w toczących się na jej łonie dyskusjach związanych z dziejami wczesnośredniowiecznej Słowiańszczyzny.

Pisząc o naukowym rodowodzie G. Labudy, dla którego inspiracją stały się cele i założenia badawcze Tymienieckiego, Widajewicza i Kostrzewskiego, należy jednak stwierdzić, że jego prace ( poświęcone Słowiańszczyźnie, początkom państw słowiańskich lub politycznym i cywilizacyjnym kontaktom Słowian i ich państw z ludami i monarchiami germańskimi - czy to z Królestwem Wschodnich Franków lub późniejszym Cesarstwem ottońskim i salickim, z wczesnośredniowieczną Skandynawią, czy Polski z Zakonem Krzyżackim - wreszcie dotyczące politycznej i kulturowej granicy polsko-niemieckiej w średniowieczu) były w zupełności wolne od zaangażowania ideologicznego. Przyjęte przez uczonego założenie badawcze: ukazanie Słowian, ich wczesnośredniowiecznej kultury społecznej i politycznej, państwowości jako niezbywalnej części Europy merowińskiej, karolińskiej i postkarolińskiej, można poniekąd porównać do twórczości Kasjodora i Jordanesa. Pragnęli oni ukazać Gotów jako pełnoprawnych współuczestników świata cywilizacji śródziemnomorskiej, dowodzili zatem ich pokrewieństwa z ludami świata hellenistycz- 
nego - tworząc jednak ową historiograficzną wizję ze z góry przyjętą tezą. G. Labuda natomiast (kierując się oczywiście założeniem o istotnej, niemożliwej do pominięcia roli średniowiecznych Słowian, w tym Polaków, w tworzenie Europy łacińskiej) prowadził swe badania i publikował ich wyniki sine ira et studio.

W odróżnieniu od twórczości A. Gieysztora historiograficzne dzieło G. Labudy szczęśliwie doczekało się, w ogłoszonej drukiem z okazji siedemdziesięciolecia jego aktywności naukowej księdze jubileuszowej, obszernego i kompetentnego podsumowania naukowego ${ }^{36}$. Wśród artykułów zamieszczonych w zbiorowym tomie autorstwa historyków poznańskich, warszawskich, krakowskich, lubelskich, wrocławskich i czeskich znalazło się studium Jerzego Strzelczyka poświęcone badaniom Labudy nad wczesną Słowiańszczyzną i kontaktami polsko-niemieckimi ${ }^{37}$.

36 Naukowe dzieto Gerarda Labudy, red. J. Dobosz, Poznań 2006. W stosunku do naukowego dzieła A. Gieysztora zostały podjęte dwie podobne próby, żadna z nich jednak nie owocowała równie imponującym rezultatem. Pierwszą z nich jest wydanie referatów wygłoszonych na jednodniowej sesji naukowej w Rzymie, poświęconej dziełu naukowemu Gieysztora: Aleksander Gieysztor 1916-1999 uomo e studioso: atti della Giornata di Studio svoltasi all'Accademia Polacca di Roma e all'Istituto Polacco di Roma il 15 maggio 2000, red. K. Żaboklicki, Varsavia-Roma 2002. W owej liczącej kilkadziesiąt stron książeczce na szczególną uwagę zwracają zwięzłe artykuły: S. Graciottiego, L'Europa di Aleksander Gieysztor, [w:] tamże, s. 15-24; H. Manikowskiej, Gieysztor come storico della cultura - i temi e i metodi di ricerca, [w:] tamże, s. 25-32; T.H. Orłowskiego, Aleksander Gieysztor e l'iconografia del potere, [w:] tamże, s. 33-39 i H. Samsonowicza, Aleksander Gieysztor, historien de l'Europe, [w:] tamże, s. 54-58; zob. też: A. Esch, Aleksander Gieysztor e la storiografia tedesca, [w:] tamże, s. 12-14. W stulecie urodzin A. Gieysztora ukazała się imponujących rozmiarów praca zbiorowa pióra wielu wybitnych autorów: Aleksander Gieysztor: człowiek i dzieło, red. M. Koczerska, P. Węcowski, Warszawa 2016; znakomitą część owej książki zajmują jednak artykuły podsumowujące działalność publiczną, społeczną i wojenną Gieysztora: w państwie podziemnym, jako wieloletniego dyrektora Instytutu Historycznego Uniwersytetu Warszawskiego i Zamku Królewskiego w Warszawie, prezesa Polskiej Akademii Nauk, nauczyciela akademickiego, wreszcie wspomnienia osobiste jego przyjaciół i uczniów. Artykułów ściśle naukowych jest zaledwie kilka, a jedynie dwa stanowią próbę podsumowania dorobku naukowego A. Gieysztora: H. Samsonowicz, Aleksander Gieysztor i badania europejskiego średniowiecza, [w:] tamże, s. 135-141 oraz S. Suchodolski, Aleksander Gieysztor a numizmatyka, tamże, [w:] s. 142-150; znakomity artykuł S. Byliny, Na moście, pod mostem, przy grobli, u mlyna, [w:] tamże, s. 11-21, stanowiący krótkie studium elementów polskiej duchowej kultury ludowej tkwiących korzeniami w pierwotnych wierzeniach Słowian, jest jedynie inspirowany wykorzystaniem przez A. Gieysztora źródeł folklorystycznych w jego rekonstrukcji mitologii słowiańskiej.

37 J. Strzelczyk, Gerard Labuda jako historyk wczesnej Stowiańszczyzny i kontaktów polskoniemieckich, [w:] Naukowe dzieło Gerarda Labudy, s. 95-110; również tenże, Gerard Labuda jako historyk wczesnej Stowiańszczyzny i stosunków stowiańsko-niemieckich, Acta Cassubiana 19 (2017), s. 19-32. 
Artykuł ten w znacznym zakresie ułatwia podjęcie się podobnego zadania. Tytuł artykułu Strzelczyka nie odzwierciedla jednak w pełni nie tylko powszechnodziejowych - choć zwykle odnoszonych do wczesnośredniowiecznej Polski - zainteresowań badawczych Labudy, lecz także treści owego studium jego autorstwa. Poza wymienionymi przez J. Strzelczyka stosunkami polsko-niemieckimi w średniowieczu i „Europą słowiańską” przedmiotem żywego zainteresowania Labudy były przez kilkadziesiąt lat źródła skandynawskie i anglosaskie, rozpatrywane w szczególności w kontekście badań nad Słowiańszczyzną i wczesną historią monarchii piastowskiej. Opracowane przez G. Labudę owe antologie i wybory tekstów, wydawane w kilku odsłonach na przestrzeni kilkudziesięciu lat, pod względem zawartości bywały częściowo powtarzalne, zawsze jednak opatrzone mniej lub bardziej obszernym, lecz treściwym komentarzem, opartym na własnych aktualnych badaniach, podsumowującym zarazem aktualny światowy stan wiedzy na ich temat ${ }^{38}$. Wśród źródeł wskazywanych przez G. Labudę jako kluczowe do poszerzenia wiedzy na temat późnostarożytnej i wczesnośredniowiecznej Słowiańszczyzny i wczesnego państwa polskiego znalazły się, oprócz często rozpatrywanych źródeł pochodzących z kręgu kultury bizantyńskiej - jak Ptolemeusz, Jordanes, Jan z Efezu, Teofilakt Simokatta, Pseudo-Maurycy, Konstantyn Porfirogeneta - i arabskiej lub perskiej: al-Mas 'ūdī, Ibn Rustah czy Gardīzī, wreszcie wschodniofrankijskiej i niemieckiej: Geograf Bawarski, Herbord, Helmold, Adam z Bremy, także przekazy skandynawskie i staroangielskie: Pieśń o Hunach, Hervarar saga ok Heiðreks (Saga o Hervarach i Heidreku), tzw. „Opis Europy” Alfreda Wielkiego, pisma Ohthere'a i Wulfstana, staroangielski poemat podróżniczy Widsidh, a także Pieśn o Rolandzie ${ }^{39}$.

Należy przy tym podkreślić, bezcenny dla innych polskich badaczy średniowiecza, lecz również dla uniwersyteckiej dydaktyki historii średniowiecznej w Polsce, trud Labudy jako wydawcy przekładów źródeł lub fragmentów źródłowych. W szczególności jednak, jak się wydaje, cenił uczony doniosłość skandynawskich źródeł wczesnośredniowiecznych i ich znaczenie dla badań nad Słowiańszczyzną i najstarszą Polską, co nie umniejsza bynajmniej jego biegłości w historii nordyckiej. Świadectwem zaangażowania G. Labudy w udostępnienie tych materiałów polskim historykom, a zarazem polskiemu czytelnikowi - miłośnikowi historii lub dawnej literatury - jest jego

38 G. Labuda, Stowiańszczyzna pierwotna: wybór tekstów, Poznań 1954; tenże, Źródła, sagi i legendy do najdawniejszych dziejów Polski, Warszawa 1960; Źródła skandynawskie i anglosaskie do dziejów Stowiańszczyzny, wyd. G. Labuda, Warszawa 1961. Zob. też przypisy następne.

39 G. Labuda, Słowiańszczyzna starożytna i wczesnośredniowieczna. Antologia tekstów źródłowych, Poznań 1999. 
udział w polskich edycjach Sagi rodu z Laxdalu ${ }^{40}$ i Sagi o Egilu ${ }^{41}$ jako autora obszernych i erudycyjnych komentarzy historycznych do tych źródeł. Było to zapewne pokłosie zainteresowania G. Labudy Sagą o Styrbjörnie: poświęcił jej w latach pięćdziesiątych obszerne studium, którego punktem ciężkości stało się zwrócenie uwagi na stosunki polsko-szwedzkie w okresie powstania zarówno monarchii Piastów, jak najstarszego państwa szwedzkiego ${ }^{42}$. Nurt badawczy związany ze stosunkami skandynawsko-słowiańskimi we wczesnym średniowieczu zaowocował w latach sześćdziesiątych dwoma artykułami ${ }^{43}$, starogermańskie zaś przekazy mityczne czy legendarne jako źródła do dziejów Słowian zachodnich powróciły w krąg zainteresowań badawczych G. Labudy w postaci obszernej rozprawy Stowianie, Goci i Hunowie, opublikowanej w tomie II Fragmentów dziejów Stowiańszczyzny Zachodniej ${ }^{44}$. W Źródłach, sagach i legendach do najdawniejszych dziejów Polski znalazły się z kolei rozprawy dotyczące: podań o gocko-huńskiej rywalizacji w dorzeczu Wisły ${ }^{45}$, anglosaskiego obrazu ziem słowiańskich pod koniec IX stulecia ${ }^{46}$ oraz wiadomości o Słowiańszczyźnie i wczesnośredniowiecznej Polsce odnajdowanych w Pieśni o Rolandzie ${ }^{47}$.

Stosunki Polski wczesnopiastowskiej z Cesarstwem oraz niektóre zagadnienia historii średniowiecznych Niemiec, w szczególności w perspektywie problematyki polskiej, lecz także zaangażowanie Labudy w toczącą się ówcześnie dyskusję histo-

40 Tenże, O islandzkich sagach rodowych, [w:] Saga rodu z Laxdalu, ze staroislandzkiego przeł. A. Załuska-Strömberg, posłowie napisał G. Labuda, Poznań 1973, s. 192-206.

41 Tenże, Posłowie do Sagi o Egilu synu Grima Eysego, [w:] Saga o Egilu, ze staroislandzkiego przeł. A. Załuska-Strömberg, posłowie napisał G. Labuda, Poznań 1974, s. 214-244.

42 Tenże, Saga o Styrbjörnie, jarlu Jómsborga ( $z$ dziejów stosunków polsko-szwedzkich $w$ X wieku), Slavia Antiqua 4 (1953), s. 283-337.

43 Tenże, Slavs in early mediaeval Pomerania and their relations with Scandinavians in the $9^{\text {th }}$ and $10^{\text {th }}$ centuries, [w: ] Poland at the XI ${ }^{\text {th }}$ International Congress of Historical Sciences in Stockholm, Warszawa 1960, s. 61-80; tenże, Polska a Skandynawia w IX-X w., [w:] Poczatki państwa polskiego. Księga Tysiąclecia, red. K. Tymieniecki, współred. G. Labuda, H. Łowmiański, t. 1, Poznań 1962, s. 299-317.

44 Tenże, Słowianie, Goci i Hunowie, [w:] tegoż, Fragmenty dziejów Stowiańszczyzny Zachodniej, Poznań 1964, s. 22-106.

45 Tenże, Podstawy historyczne legendy o walkach gocko-huńskich nad Wisła (Herwararsaga i Pieśn o Hunach), [w: ] tegoż, Źródta, sagi i legendy, s. 91-151.

46 Tenże, Ziemie polskie i nadbattyckie w opisie Europy króla Alfreda, [w:] tegoż, Źródła, sagi i legendy, s. 11-90; tenże, Widsith, [w:] tegoż, Źródła, sagi i legendy, s. 153-198.

47 Tenże, Słowiańszczyzna Zachodnia i Polska w „Pieśni o Rolandzie”, [w:] tegoż, Źródła, sagi i legendy, s. 199-241. 
riograficzną w Niemczech, zostały niezwykle rzeczowo streszczone i przeanalizowane przed kilkunastu laty przez J. Strzelczyka ${ }^{48}$, nie ma zatem potrzeby powtarzać w tym miejscu jego wniosków. W kontekście stosunków polsko- oraz ogólniej słowiańsko-niemieckich i ich obrazu w historiografii XX w. nie sposób jednak pominąć dwóch ważnych prac G. Labudy ściśle związanych z ową niełatwą pod względem historycznym, historiograficznym oraz politycznym, kwestią. Mowa tu o Powstaniach Stowian połabskich ${ }^{49}$ oraz o napisanych wraz z Marianem Biskupem Dziejach Zakonu Krzyżackiego $w$ Prusach ${ }^{50}$. Koniecznie należy tu podkreślić, że poświęcone tematyce niemieckiej studia poznańskiego mediewisty w żadnym stopniu - choć byłoby to łatwo zrozumiałe w latach bezpośrednio po drugiej wojnie światowej - nie noszą znamion historycznego resentymentu, owszem, mogą uchodzić za wzór historiograficznego obiektywizmu. Dzieje Zakonu Krzyżackiego w Prusach z kolei stanowią być może pierwsze w Polsce dzieło historiograficzne poświęcone historycznej emanacji „odwiecznego wroga”, które - mimo utrwalonego w PRL, a przecież mającego zadawnione historyczne konotacje przekazu - koncentrowało się nie tylko na obiektywnym przedstawieniu syntezy dziejów Zakonu na ziemiach polskich i z Polską średniowieczną sąsiadujących, lecz również ukazującym ogromny cywilizacyjny postęp, jaki prócz oczywistego politycznego i militarnego zagrożenia dla Polski i Litwy wniosło na ziemie nadbałtyckie powstanie i trwanie przez trzy stulecia państwa zakonu krzyżackiego. Interesując się pojęciem oraz funkcjonowaniem politycznej i kulturowej granicy polsko-niemieckiej, G. Labuda nie wahał się jednak wchodzić w polemiki ze stanowiskiem dawnej lub nowszej nauki niemieckiej bądź polskiej. Był skądinąd w środowisku nauki niemieckiej niezwykle wysoko ceniony, w szczególności chyba za badania słowianoznawcze: świadczy o tym nie tylko kilkadziesiąt haseł dotyczących średniowiecznej Słowiańszczyzny w pomnikowym dziele dwudziestowiecznej historiografii niemieckiej - Lexikon des Mittelalters ${ }^{51}$ - lecz także autorstwo

\footnotetext{
48 J. Strzelczyk, Gerard Labuda jako historyk wczesnej Stowiańszczyzny, s. 102-109.

49 G. Labuda, Powstania Stowian połabskich u schytku X wieku, Slavia Occidentalis 18 (1939-1947), s. 153-200, również tenże, Fragmenty dziejów Słowiańszczyzny Zachodniej, t. 1, Poznań 1961, s. 205-246.

50 M. Biskup, G. Labuda, Dzieje Zakonu Krzyżackiego w Prusach. Gospodarka - Społeczeństwo - Państwo - Ideologia, Gdańsk 1986.

51 Także A. Gieysztor był autorem wielu haseł w Lexikon des Mittelaters, w znakomitej większości dotyczyły one jednak historii średniowiecznej Polski, jedynie nieliczne związane były z historią i kulturą innych krajów słowiańskich, jak np. Prokop, Heiliger († 1053), [w: ] Lexikon des Mittelaters, Bd. 7, München 1995, kol. 244-245.
} 
w Festschriftach niemieckich historyków średniowiecza, w tym jednego z największych luminarzy niemieckiego słowianoznawstwa - Herberta Ludata. W tym tomie ogłosił on artykuł poświęcony państwu (civitas) połabskiego księcia Dragowita, już to sojusznika Franków (Karola Młota), już to ich przeciwnika, w końcu zaś - wasala Karola Wielkiego ${ }^{52}$.

Większość rozproszonych prac G. Labudy dotyczących polsko-niemieckiego sąsiedztwa i wspólnej polsko-niemieckiej historii, wydanych w ciągu uprzednich 50 lat jego pracy po polsku i po niemiecku, została opublikowana w zbiorze Polskoniemieckie rozmowy o przeszłości z roku $1996^{53}$. W kolejnych latach G. Labuda jeszcze powracał, niekiedy w bardzo obszernych studiach, do kwestii sąsiedztwa polsko-niemieckiego, kontynuując przede wszystkim najżywiej go interesujący i uznawany za kluczowy wątek owej problematyki, to jest kwestię stosunku prawnego pomiędzy Cesarstwem lub Królestwem Niemieckim a monarchią Piastów oraz księstwami dzielnicowymi i terytorialnymi pogranicza polsko-niemieckiego ${ }^{54}$.

Zapewne właśnie wrażliwość Labudy na prawno-polityczne wątki w badaniach historycznych skierowała go ku zajęciu się historią polskiej dyplomacji, której dwie syntezy: dłuższą, choć obejmującą okres tylko do początku wieku XIV ${ }^{55}$, oraz znacznie zwięźlejszą, lecz doprowadzoną do końca panowania Piastów, opublikował w pracach zbiorowych z lat 1980 i $2002^{56}$. Warto nadmienić znaczącą różnicę między

52 G. Labuda, Civitas Dragaviti: $z$ u den fränkisch-slavischen Beziehungen am Ende des 8. Jahrhunderts, [w:] Europa slavica - Europa orientalis. Festschrift für Herbert Ludat zum 70. Geburtstag, wyd. K.D. Grothusen, K. Zernack, Berlin 1980, s. 87-98.

53 Tenże, Polsko-niemieckie rozmowy o przeszłości. Zbiór rozpraw i artykułów, Poznań 1996.

54 Tenże, $O$ stosunkach prawno-politycznych państwa polskiego z państwem niemieckim $w X$ i XI wieku [W zwiazku z praca: J. Sochacki, Stosunki publiczno-prawne między państwem polskim a cesarstwem rzymskim w latach 963-1102, Stupsk-Gdańsk 2003], Czasopismo Prawno-Historyczne 57 (2005), s. 327-378; tenże, Podstawy polityczno-prawne kupna Pomorza Gdańskiego przez Zakon Krzyżacki od margrabiów brandenburskich w r. 1309/1310, Roczn. Hist. 71 (2005), s. 31-61; tenże, O zakresie rzekomych uprawnień Królestwa Niemieckiego i Marchii Brandenburskiej nad całym Pomorzem we wczesnym średniowieczu, Roczn. Hist. 73 (2007), s. 17-34.

55 Tenże, Historia dyplomacji - przedmiot i zarys wykładu i Dyplomacja polska wczesnego feudalizmu X w. 1306 r., [w:] Historia dyplomacji polskiej (potowa X-XX w.), t. 1-5, red. G. Labuda, Warszawa 1980, tu: t. 1, Połowa X w. - 1572, red. M. Biskup, s. 9-31 i 33-218 (wydanie 2: Warszawa 1982).

56 G. Labuda, Dyplomacja polska w okresie panowania dynastii piastowskiej (wiek X 1370), [w:] Historia dyplomacji polskiej X-XX w., red. G. Labuda, W. Michowicz, Warszawa 2002, s. 11-63. 
tymi publikacjami. Pierwsza wersja, przygotowywana pod patronatem Ministerstwa Spraw Zagranicznych PRL, w naturalny sposób musiała oddawać hołd historycznej i współczesnej racji stanu - i polityki historycznej - takiej, jak pojmowały ją władze partii komunistycznej, a także naukowej nomenklaturze, jaka obowiązywała w kręgu władz PRL (stąd tytuł rozdziału autorstwa G. Labudy: Dyplomacja polska wczesnego feudalizmu - choć powątpiewamy dziś nie tylko w związek zjawiska feudalizmu ze zjawiskiem dyplomacji, lecz również w prawomocność użycia pojęcia „feudalizm” dla Polski między X a początkiem XIV w.). Z kolei wersja z roku 2002 była nie tylko znacznie skrócona; usunięto z niej wszystkie naleciałości ideologiczne, poprzednio wymuszone przez decydujące czynniki polityczne. Obie te syntezy są oczywiście publikacjami dotyczącymi dziejów dyplomacji polskiej, lecz z samej definicji pojęcia i zjawiska historycznego, jakim jest dyplomacja, wynika w oczywisty sposób, że studium jej poświęcone musi stanowić zarazem studium historii powszechnej, w przypadku średniowiecza - europejskiej.

Zainteresowanie G. Labudy dziejami dyplomacji wiązało się ściśle z wcześniej wzmiankowaną wrażliwością uczonego na historyczne kwestie polityczno-prawne i ich funkcję - i wpływ - w toku dziejów. Bez wątpienia wynikało stąd powstanie dwóch bardzo znaczących artykułów - jednego popularnonaukowego, a przecież niezwykle ważkiego intelektualnie eseju, dotyczącego kształtowania się systemu monarchii, a w konsekwencji ludów (narodów / wspólnot politycznych) we wczesnośredniowiecznej Europie ${ }^{57}$, i drugiego - na temat miejsca wejścia monarchii wczesnopiastowskiej w system geopolityczny Europy w wieku $X^{58}$.

Odrębnym dziełem w dorobku uczonego jest Rozwój metod dziejopisarskich od starożytności do wspótczesności ${ }^{59}$, jedno z najpóźniejszych, dojrzałych jego dzieł, tym razem w dziedzinie historii historiografii powszechnej. Podobnie jak w przypadku wielu innych dzieł Labudy ambicją autora jest tu w znacznym stopniu ukazanie miejsca polskiej historiografii w ujęciu uniwersalnym, a zarazem porównawczym. Jak sam pisze we wstępie do książki, przedmiotem jego zainteresowania było, w jaki sposób

57 Tenże, Ksztaltowanie się systemu państw i narodów europejskich, [w:] Narodziny średniowiecznej Europy, red. H. Samsonowicz, Warszawa 1999, s. 278-336.

58 Tenże, Polska piastowska $X$ wieku $w$ systemie państw i narodów europejskich wczesnego średniowiecza, [w: ] Civitas Schinesghe. Mieszko I i początki państwa polskiego, red. J.M. Piskorski, Poznań 2004, s. 13-25.

59 Tenże, Rozwój metod dziejopisarskich od starożytności do współczesności, Część 1: Do schyłku XIX wieku, Poznań-Wrocław 2003; tenże, Rozwój metod dziejopisarskich od starożytności do wspótczesności, Część 2: Wiek XX, Poznań 2010. 
autorzy dzieł historycznych pisali i jak rozumieli historię. Owoce swej refleksji nad historią dziejopisarstwa G. Labuda przedstawił przez pryzmat stosowanych przez historyków metod badania, rekonstruowania i opowiadania historii na przestrzeni dwudziestu pięciu stuleci, od jego starożytnych początków (choć należy zauważyć, że metodom dziejopisarskim poprzedzającym powstanie w XIX w. metody genetycznej, nazwanej także historyczno-krytyczną lub rozwojową, poświęcił jedynie trzy krótkie rozdziały $\left.{ }^{60}\right)$. W owej imponującej książce ukazał zarazem różnorakie formy dziejopisarstwa, kładąc akcent na rozwój gatunkowy piśmiennictwa historycznego lub historiograficznego. $\mathrm{Z}$ jednej strony zaprezentował tu zależność stosowanych i postulowanych przez dziejopisów metod poznania historycznego od reprezentowanej przez nich formacji umysłowej, będącej konsekwencją obrazu intelektualnego epoki i środowiska, w których działali, z drugiej - swoją własną refleksję na temat postępu (a nawet - jeśli można użyć takiego sformułowania - historii postępu) w naukach historycznych i na temat perspektyw ich dalszego rozwoju. Tak pojętą historię historiografii polskiej ukazał jako część historii historiografii powszechnej, dla okresu do połowy wieku XX - co oczywiste - europejskiej.

Jednak najważniejszym bodaj z dzieł G. Labudy w dziedzinie historii powszechnej średniowiecza, wyrastającym zarazem z korzeni jego pasji słowianoznawczej, jest niewątpliwie Państwo Samona ${ }^{61}$. Jest to jedna z wczesnych jego prac, wracam do niej jednak u zwieńczenia tej części artykułu nie tylko ze względu na jej doniosłe miejsce w historiografii, lecz także z racji stosowanej w niej przez autora metody, której pozostał wierny w całym swoim życiu naukowym, a której dzieło to wciąż pozostaje niedoścignionym mistrzowskim popisem. Jest to niewątpliwie metoda nazwana przez samego uczonego genetyczną (historyczno-krytyczną) z zaznaczeniem, że wiąże się ona nierozerwalnie z pozytywizmem historycznym G. Labudy jako celem poznania oraz optymizmem poznawczym będącym latarnią, która przyświecała całej jego drodze naukowej ${ }^{62}$. Państwo Samona to dzieło pomnikowe zarówno w historiografii polskiej, jak i światowej, w zakresie historii wczesnej Słowiańszczyzny i genezy państw słowiańskich. Pod względem metodologicznym - w konsekwencji wspomnianego już pozytywistycznego optymizmu poznawczego - może uchodzić za należącą do

60 Tenże, Rozwój metod dziejopisarskich, Część 1, rozdz. I: Metoda logograficzna, rozdz. II: Metoda narracyjna, rozdz. III: Metoda pragmatyczna, s. 15-40.

61 Tenże, Pierwsze państwo stowiańskie. Państwo Samona, Poznań 1949 (dalej cyt.: Państwo Samona).

62 Metodzie genetycznej (historyczno-krytycznej) i rozwojowej G. Labuda poświęcił obszerny rozdział w swym Rozwoju metod dziejopisarskich, Część 1, s. 41-75. 
„starej szkoły” cofającej się przed koniecznym niekiedy przyznaniem ignoramus et ignorabimus. Jest jednak zarazem wzorcowym przykładem analitycznego podejścia do zastanego stanu badań i niemal akrybicznej źródłoznawczej analizy krytycznej. Autor Państwa Samona nie pominą żadnego z przekazów, które mogłoby być przydatne do wydobycia jakichkolwiek informacji pozwalających na analizę i interpretację szczupłej podstawy źródłowej współczesnej powstaniu pierwszego państwa Słowian ( $w$ istocie jedynie trzy krótkie passusy w kronice Fredegara). Zarazem nie omieszkał, dzięki znakomitemu panowaniu nad wszystkimi wykorzystywanymi źródłami i nad literaturą ich dotyczącą, eliminować, bezwzględnie stosując „brzytwę Ockhama”, wszelkich informacji źródłowych uznanych za zbędne, wtórne lub nieoparte na rzeczywistej, choćby pośrednio zdobytej, wiedzy autorów. W ten sposób odrzucił np. Conversio Bagoariorum et Carantanorum z korpusu źródeł przydatnych do rekonstrukcji państwa Samona, uznając jego całkowitą zależność od Gesta Dagoberti regis. Zarazem rozdziały Analiza krytyczno-literacka źródeł o Samonie i Kronika Fredegara, jako źródto oraz ekskursy: Miejsce powstania kroniki Fredegara i Przektad i egzegeza rozdz. 48 ks. IV kroniki Fredegara, mimo upływu lat i postępu w badaniach historycznych, ogromnego przyrostu wiedzy, który dokonał się w naturalny sposób w ciągu siedmiu dziesiątek lat od ogłoszenia pierwszego wydania Państwa Samona drukiem, wciąż pozostają mistrzowskim popisem pozytywistycznej metody historyczno-krytycznej ${ }^{63}$. Z kolei przejawem „rozwojowości” immanentnie związanej z metodą genetyczną stosowaną przez G. Labudę są partie książki poświęcone wyprawom Awarów na państwo Franków w drugiej połowie VI w. i chronologii wojen Bizancjum z Awarami i Słowianami pod koniec VI stulecia ${ }^{64}$ - to ostatnie ogłoszone jako odrębne studium w języku francuskim ${ }^{65}$.

Państwo Samona jest, jak się rzekło, dziełem pomnikowym. Do dziś w historiografii światowej nie pojawiła się nowsza monografia, która zaproponowałaby znacząco inną niż Labudy wizję owej pierwszej monarchii słowiańskiej i jej dziedzictwa historycznego. Zawarte w owym studium tezy, dotyczące zasięgu terytorialnego pań-

63 G. Labuda, Państwo Samona, rozdz. 2: Analiza krytyczno-literacka źródeł o Samonie, s. 30-51 i Kronika Fredegara jako źródło, s. 52-92 oraz ekskursy: I. Miejsce powstania kroniki Fredegara, s. 296-320 i II. Przekład i egzegeza rozdz. 48 ks. IV kroniki Fredegara, s. 321-331. 64 Tamże, Ekskurs III: Wyprawy Awarów na Frankonię w drugiej połowie VI wieku, s. 332-340, Ekskurs IV: Chronologia wojen bizantyńsko-awarsko-stowiańskich w schyłku VI wieku, s. 341-350.

65 G. Labuda, Chronologie des guerres de Byzance contre les Avars et les Slaves à la fin du VI siècle, Byzantinoslavica 11 (1954), z. 2, s. 166-173. 
stwa Samona i strefy jego politycznych wpływów (np. księstwo Derwana i jego lokalizacja), polemiczne wobec hurrapatriotycznych tez Františka Palackiego, podobnie jak wobec redukcjonistycznego podejścia do trwałości dziedzictwa państwa Samona - w większości przyjęły się w historiografii czeskiej i słowackiej. Według G. Labudy państwo to oczywiście rozpadło się po śmierci jego twórcy, pozostawiło jednak po sobie zalążki organizacji państwowych (drobne księstwa na dalekich peryferiach świata frankijskiego, dlatego niezauważalne przez źródła), które w następnych pokoleniach przekształciły się w Wielką Morawę. Istotne i interesujące poznawczo korekty poglądów G. Labudy lub uzupełnienia pojawiły się dopiero na przełomie lat siedemdziesiątych i osiemdziesiątych w historiografii niemieckiej, w szczególności w postaci serii artykułów Heinricha Kunstmanna ${ }^{66}$.

\section{III.}

Naukowe dzieło G. Labudy w dziedzinie badań powszechnodziejowych jest wręcz przytłaczające nawet dla zawodowego historyka. Nie jestem w stanie w tym miejscu poddać go kompletnej analizie, na którą jak najbardziej zasługuje. Mogłoby ono z pewnością stać się przedmiotem rozprawy doktorskiej czy nawet habilitacyjnej $\mathrm{z}$ zakresu historii historiografii, do której uczony ten wszedł już w pierwszych latach swego naukowego życia ${ }^{67}$. Podobną trudność stwarza takie samo zadanie w odniesieniu do twórczości A. Gieysztora. W wypadku obu tych wielkich uczonych

66 H. Kunstmann, Wo lag das Zentrum von Samos Reich?, Die Welt der Slaven n.s. 5 (1981), s. 67-101; tenże, Was besagt der Name Samo, und wo liegt Wogastisburg?, Die Welt der Slaven n.s. 3 (1979), s. 1-21; tenże, Samo, Dervanus und der Slovenenfürst Wallucus, Die Welt der Slaven n.s. 4 (1980), s. 171-177; tenże, Über die Herkunft Samos, Die Welt der Slaven n.s. 4 (1980), s. 293-313; tenże, Noch einmal Samo und Wogastisburc, Die Welt der Slaven n.s. 7 (1983), s. 354-363. Zob. też: A. Avenarius, Avary i slavjane. „Deržava Samo”, [w:] Ranne-feodalnyje gosudarstva i narodnosti (južnyje i zapadnyje slavjane VI-XII vv.), Moskva 1991, s. 26-37; M. Eggers, Samo - „der erste König der Slawen”. Eine kritische Forschungsübersicht, Bohemia. Zeitschrift für Geschichte und Kultur der Böhmischen Länder 42 (2001), s. 62-83; P.J. Geary, Slovenian Gentile Identity: From Samo to the Fürstenstein, [w:] Franks, Northmen, and Slavs. Identities and State Formation in Early Medieval Europe, red. I.H. Garipzanov, P. Geary, P. Urbańczyk, Turnhout 2008, s. 243-258.

67 Nie sposób omówić tu (czy choćby wymienić) wszystkich czy nawet najważniejszych studiów G. Labudy odnoszących się do historii powszechnej. Pozwalam sobie odesłać zainteresowanego czytelnika do ogólnego - niemal kompletnego, bo obejmującego lata 1935-2006 - zestawienia Bibliografia prac Profesora Gerarda Labudy, [w: ] Naukowe dzieło Gerarda Labudy, s. $162-282$. 
podstawową trudność stanowi rozproszenie ich mniejszych studiów, jeśli zaś chodzi o Gieysztora - także wielokierunkowość jego zainteresowań w zakresie historii powszechnej. Pozwolę sobie zatem jedynie na naszkicowanie wniosków, jakie płyną z lektury dorobku tych dwóch gigantów polskiej historiografii XX i początku XXI w.

1. O ile zainteresowania G. Labudy od początku jego drogi naukowej podążały w kierunku słowianoznawstwa - nawet jeśli już w okresie przedwojennym dostrzegał istotną potrzebę rekonstruowania wczesnych dziejów Polski i Europy Środkowej w zestawieniu z analizą źródeł nordyckich lub anglosaskich, o tyle A. Gieysztor we wczesnych latach aktywności naukowej wydawał się adeptem przede wszystkim historii zachodnioeuropejskiej, szczególnie interesując się państwem Franków i wczesnośredniowiecznym Zachodem romańskim. Dopiero po wojnie, w konsekwencji zmienionej sytuacji geopolitycznej Polski, nie mogąc kontynuować studiów nad problematyką średniowiecza zachodnioeuropejskiego, dołączył do nurtu słowianoznawczego, m.in. włączając się aktywnie w prace Kierownictwa Badań nad Początkami Państwa Polskiego. Po roku 1956, bez wątpienia orientując swą aktywność badawczą na najbliższe mu środowisko paryskie i włoskie - zafascynowane Rosją - swoje badania w największym stopniu poświęcił Rusi i publikacjom dotyczącym Słowiańszczyzny, podczas gdy G. Labuda, kontynuując tradycję poznańską, skupiał się na Słowiańszczyźnie zachodniej i - w nieco mniejszym stopniu - południowej. Słowianoznawcze badania Labudy były skupione przede wszystkim na aspektach powstawania i funkcjonowania państw Słowian, on sam zaś przykładał ogromną wagę do uznawanych przez siebie za poznawczo kluczowe wątków prawno-politycznych; Gieysztor natomiast poświęcił się w większym stopniu historii kultury z zastosowaniem metody porównawczej - w ten sposób konstruował obraz Europy Środkowo-Wschodniej i Polski jako uczestników średniowiecznej cywilizacji europejskiej.

2. G. Labuda, konstruując własną wizję historii, w tym dziejów powszechnych (europejskich), szedł zwykle drogą od ogółu do szczegółu. Z badanych przez niego wielkich problemów historii europejskiej - dotyczących głównie instytucji państwowych zachodniej Słowiańszczyzny i jej sąsiedztwa politycznego i cywilizacyjnego - wyprowadzał wnioski szczegółowe, objaśniające kluczowe wątki dziejów wczesnośredniowiecznej Europy.

3. Badania powszechnodziejowe (europejskie) A. Gieysztora - od czasów, gdy zajmował się jeszcze w całości wątkami zachodnioeuropejskimi, podążały raczej od szczegółu do ogółu. Precyzyjnie definiując interesujące go szcze- 
gółowe wątki historii średniowiecznej Europy, dotyczące najpierw Zachodu, a od przełomu lat czterdziestych i pięćdziesiątych głównie Europy Środkowo-Wschodniej, Gieysztor - na podstawie analizy i interpretacji pojedynczych zjawisk, procesów i faktów historycznych - proponował kategoryzację i interpretację zagadnień szczegółowych w taki sposób, aby prowadziły one do ogólnych, syntetycznych wniosków poznawczych.

4. G. Labuda prowadził badania powszechnodziejowe skupione na rekonstrukcji najdawniejszych dziejów Słowiańszczyzny zachodniej lub jej sąsiedztwa, aby w ten sposób, w ujęciu porównawczym, precyzyjniej i głębiej poznać historię wczesnej Polski, przede wszystkim w aspekcie faktograficznym oraz prawno-politycznym; wielorakość i wielokierunkowość proponowanych przez niego wątków badawczych zawsze była podporządkowana temu celowi. Badania szczegółowe, jakie prowadził, wiodły do publikowania wniosków i prac syntetycznych.

5. Powszechnodziejowe badania A. Gieysztora były pod względem tematyki rozproszone i koncentrowały się na kilku odrębnych i niepowiązanych wzajemnie wątkach. Ogromne znaczenie miała dla A. Gieysztora metoda komparatystyczna pozwalająca - dzięki badaniom ukazującym wpływy obce w kulturze duchowej i instytucjach średniowiecznej Polski i Rusi - lepiej poznać historię średniowiecznej Europy, pojmowanej jako zjawisko rozciągłe w przestrzeni i czasie, i podlegające zmianie. Można jedynie ubolewać, że szczegółowe badania A. Gieysztora nad historią kultury i historią społeczną Europy Środkowo-Wschodniej nie doczekały się nigdy syntezy.

Nadesłany: 20 VI 2021

Nadesłany po poprawkach recenzyjnych: 15 VIII 2021

Zaakceptowany: 16 VIII 2021

Dr hab. Jerzy Pysiak

Wydział Nauk o Kulturze i Sztuce, Uniwersytet Warszawski

ul. Krakowskie Przedmieście 26/28

00-927 Warszawa

e-mail: j.pysiak@uw.edu.pl 


\section{Résumé}

\section{Aleksander Gieysztor and Gerard Labuda as Researchers in Universal History}

From the very beginning, Gerard Labuda's research interests were centred around Slavic studies. As early as in the pre-war period, Labuda attempted to reconstruct the early history of Poland and Central Europe also by analysing Nordic or Anglo-Saxon sources. In the early years of his scholarly activity, Aleksander Gieysztor was primarily interested in Western European history, particularly the Frankish Kingdom and the early medieval Roman West. It was only after the Second World War, when he could not continue his studies of Western European medieval issues, that he joined the Slavic studies movement and became involved in the work of the Research Management of the Origins of the Polish State. From the 1950s onwards, Gieysztor focused his Slavic studies on Rus', while Gerard Labuda, continuing the Poznań tradition, concentrated on Western Slavic studies. Gerard Labuda primarily investigated different aspects of the formation and functioning of Slavic states (Samo's Empire). Labuda attached great importance to what he saw as the key legal and political themes, while Gieysztor devoted himself to cultural history using the comparative method, thus constructing a picture of Central and Eastern Europe and Poland as participants in medieval European civilisation.

Translated by Agnieszka Tokarczuk

\section{Bibliografia/Bibliography}

Avenarius A., Avary i slavjane. „Deržava Samo”, [w:] Ranne-feodalnyje gosudarstva i narodnosti (južnyje i zapadnyje slavjane VI-XII vv.), Moskva 1991, s. 26-37

Biskup M., Labuda G., Dzieje Zakonu Krzyżackiego w Prusach. Gospodarka - Społeczeństwo - Państwo - Ideologia, Gdańsk 1986

Dumézil G., Les dieux des Germains: essai sur la formation de la religion scandinave, Paris 1959

Dumézil G., Mythe et épopée, t. 1: L'idéologie des trois fonctions dans les épopées des peuples indo-européens, Paris 1968

Eggers M., Samo - „der erste König der Slawen”. Eine kritische Forschungsübersicht, Bohemia. Zeitschrift für Geschichte und Kultur der Böhmischen Länder 42 (2001), s. 62-83

Einhard, Życie Karola Wielkiego, przeł. J. Parandowski; wstępem i objaśnieniami opatrzył A. Gieysztor, Wrocław 1950 
Einhard, Życie Karola Wielkiego, z oryginału lacińskiego przełożył, wstępem i objaśnieniami zaopatrzył J. Parandowski, Warszawa-Lwów 1935

Geary P.J., Slovenian Gentile Identity: From Samo to the Fürstenstein, [w:] Franks, Northmen, and Slavs. Identities and State Formation in Early Medieval Europe, ed. by I.H. Garipzanov, P. Geary, P. Urbańczyk, Turnhout 2008, s. 243-258

Gejŝor [Gieysztor] A., Mitologiâ na Slavânite, prevela ot polski K. Mitova, Sofiâ 1986 Gieysztor A., En guise de conclusion: la religion traditionnelle slave et la christianisation de la Rus', changement et continuité, [w:] Proceedings of the International Congress Commemorating the Millennium of the Christianity in Rus' - Ukraine, ed. by Omeljan Pritsak and Ihor Ševčenko, Harvard Ukrainian Studies 12/13 (1988/1989), s. $870-877$

Gieysztor A., Historical similarities of Poland and Corea, Korea Observer 25 (1994), z. 3, s. 421-428

Gieysztor A., Kasztelanowie flandryjscy i polscy. Zagadnienia porównawcze, Studia historyczne 7 (1965), s. 97-107

Gieysztor A., La Polonia medioevale tra Occidente ed Oriente, Studi storici 9 (1968), z. 2 (aprile-giugno), s. 247-260

Gieysztor A., La strutturazione culturale dei paesi slavi nell alto medioevo, [w: Centri e vie di irradiazione della civiltà nell'alto medioevo, Settimane di studio del Centro Italiano di studi sull'alto medioevo 11, Spoleto 18-23 aprile 1963, Spoleto 1964, s. 371-392

Gieysztor A., Le Centre et l'Est européen au XIV siècle vus de la Méditerannée, [w: ] Mélanges en l'honneur de Fernand Braudel, t. 1: Histoire économique du monde méditerranéen 1450-1650, éd. E. Labrouste i in., Toulouse 1973, s. 219-225

Gieysztor A., L'Europe médiévale du Centre-est: frontières mouvantes de cultures, [w: ] Europa medioevale e mondo bizantino. Contatti effettivi e possibilità di studi comparati (Tavola ronda del XVIII Congresso del CISH - Montréal, 29 agosto 1995), a cura di G. Arnaldi, G. Cavallo, Roma 1997, s. 213-220

Gieysztor A., L'Europe nouvelle autor de l'An Mil. La Papauté, l'Empire et les „nouveaux venus", Roma 1997

Gieysztor A., L'héritage artistique de l'antiquité barbare et romaine sur le territoire de la Pologne, [w: ] Mélanges d'art et d'histoire. Mélanges offertes à René Crozet à l'occasion de son $70^{\text {ème }}$ anniversaire, par ses amis, ses collèques, ses élèves, éd. P. Gallais, Y.F. Riou, Poitiers 1966, s. 23-31 
Gieysztor A., Mitologia Stowian, Warszawa 1982

Gieysztor A., Mitologia Stowian, wydanie 3, rozszerzone i zmienione, wstęp K. Modzelewski; posłowie L.P. Słupecki; oprac. na podst. rękopisu A. Pieniądz, Warszawa 2006

Gieysztor A., Mytologie Slovanů, přeložila H. Komárková, Praha 2020

Gieysztor A., Polskie Millenium. Z zagadnień wspótpracy historii i archeologii wczesnodziejowej, Przegląd Historyczny 38 (1948), s. 391-412

Gieysztor A., Problem karolińskiej reformy pisma, Archeologia 5 (1952-1953), s. $155-176$.

Gieysztor A., Stowiańska wizja świata, [w: ] Alexander Gieysztor. Doctor honoris causa Universitatis Studiorum Mickiewicziane Poznaniensis, Poznań 1990, s. 29-40

Gieysztor A., Urząd wojewodziński we wczesnych państwach słowiańskich w IX-XI wieku, Archeologia Polski 16 (1971), s. 317-325

Gieysztor A., Uwagi o funkcjach społecznych apostazji i herezji w Europie wczesnośredniowiecznej, [w:] Z polskich studiów slawistycznych, seria 2: Historia, Warszawa 1963, s. 53-60

Gieysztor A., Wtadza Karola Wielkiego w opinii współczesnej, Warszawa 1938

Gieysztor A., W sprawie początków trójpolówki w Polsce i krajach sąsiednich, [w: ] Prace $z$ dziejów Polski feudalnej: ofiarowane Romanowi Grodeckiemu w 70 rocznice urodzin, red. Z. Kozłowska-Budkowa i in., Warszawa 1960, s. 71-79

Gieysztor A., Zarys dziejów pisma łacińskiego, Warszawa 1973

Gieysztor A., Ze studiów nad geneza wypraw krzyżowych. Encyklika Sergiusza IV (1009-1012), Warszawa 1948

Gieysztor A., Z zagadnień kultury staroruskiej: składniki rodzime i obce, [w:] Studia historica w 35-lecie pracy naukowej Henryka Łowmiańskiego, red. A. Gieysztor i in., Warszawa 1958, s. 73-89

Handelsman M., Badania szkoly warszawskiej nad wczesnym średniowieczem (tłum. z oryginału niemieckiego opublikowanego w 1938 r.), [w: ] Średniowiecze polskie i powszechne. Wybór pism, wyd. A. Gieysztor, Warszawa 1966, s. 343-348

Koczerska M., Aleksander Gieysztor 17 VII 1916 - 9 II 1999. Szkic biograficzny, Studia Źródłoznawcze 36 (2016), s. 1-12

Kunstmann H., Noch einmal Samo und Wogastisburc, Die Welt der Slaven n.s. 7 (1983), s. 354-363

Kunstmann H., Samo, Dervanus und der Slovenenfürst Wallucus, Die Welt der Slaven n.s. 4 (1980), s. $171-177$ 
Kunstmann H., Über die Herkunft Samos, Die Welt der Slaven n.s. 4 (1980), s. 293$-313$

Kunstmann H., Was besagt der Name Samo, und wo liegt Wogastisburg?, Die Welt der Slaven n.s. 3 (1979), s. 1-21

Kunstmann H., Wo lag das Zentrum von Samos Reich?, Die Welt der Slaven n.s. 5 (1981), s. 67-101

Labuda G., Chronologie des guerres de Byzance contre les Avars et les Slaves à la fin du $V I^{e}$ siècle, Byzantinoslavica 11 (1954), z. 2, s. 166-173

Labuda G., Civitas Dragaviti: zu den fränkisch-slavischen Beziehungen am Ende des 8. Jahrhunderts, [w:] Europa slavica - Europa orientalis. Festschrift für Herbert Ludat zum 70. Geburtstag, red. K.D. Grothusen, K. Zernack, Berlin 1980, s. 87-98

Labuda G., Dyplomacja polska wczesnego feudalizmu X w. - 1306 r., [w: ] Historia dyplomacji polskiej (połowa X-XX w.), t. I-V, red. G. Labuda, Warszawa 1980, tu: t. 1, Połowa X w. - 1572, red. M. Biskup, s. 33-218

Labuda G., Dyplomacja polska w okresie panowania dynastii piastowskiej (wiek X1370), [w: ] Historia dyplomacji polskiej X-XX w., red. G. Labuda, W. Michowicz, Warszawa 2002, s. 11-63

Labuda G., Fragmenty dziejów Stowiańszczyzny Zachodniej, t. 1, Poznań 1961 Labuda G., Historia dyplomacji - przedmiot i zarys wykładu, [w: ] Historia dyplomacji polskiej (połowa X-XX w.), t. I-V, red. G. Labuda, Warszawa 1980, tu: t. 1, Połowa $X w .-1572$, red. M. Biskup, s. 9-31

Labuda G., Ksztaltowanie się systemu państw i narodów europejskich, [w:] Narodziny średniowiecznej Europy, red. H. Samsonowicz, Warszawa 1999, s. 278-336

Labuda G., O islandzkich sagach rodowych, [w:] Saga rodu z Laxdalu, ze staroislandzkiego przeł. A. Załuska-Strömberg, posłowie G. Labuda, Poznań 1973, s. 192-206 Labuda G., O stosunkach prawno-politycznych państwa polskiego z państwem niemieckim w Xi XI wieku [W zwiazku z praca: J. Sochacki, Stosunki publiczno-prawne między państwem polskim a cesarstwem rzymskim w latach 963-1102, Stupsk-Gdańsk 2003], Czasopismo Prawno-Historyczne 57 (2005), s. 327-378

Labuda G., O zakresie rzekomych uprawnień Królestwa Niemieckiego i Marchii Brandenburskiej nad całym Pomorzem we wczesnym średniowieczu, Roczniki Historyczne 73 (2007), s. 17-34

Labuda G., Pierwsze państwo stowiańskie. Państwo Samona, Poznań 1949

Labuda G., Podstawy historyczne legendy o walkach gocko-huńskich nad Wista (Herwararsaga i Pieśn o Hunach), [w:] tegoż, Źródła, sagi i legendy do najdawniejszych dziejów Polski, Warszawa 1960, s. 91-151 
Labuda G., Podstawy polityczno-prawne kupna Pomorza Gdańskiego przez Zakon Krzyżacki od margrabiów brandenburskich w r. 1309/1310, Roczniki Historyczne 71 (2005), s. 31-61

Labuda G., Polska a Skandynawia w IX-X w., [w:] Poczatki państwa polskiego. Księga Tysiąclecia, red. K. Tymieniecki, współred. G. Labuda, H. Łowmiański, t. 1, Poznań 1962, s. 299-317

Labuda G., Polska piastowska X wieku w systemie państw i narodów europejskich wczesnego średniowiecza, [w: Civitas Schinesghe. Mieszko I i początki państwa polskiego, red. J.M. Piskorski, Poznań 2004, s. 13-25

Labuda G., Polsko-niemieckie rozmowy o przeszłości. Zbiór rozpraw i artykutów, Poznań 1996

Labuda G., Posłowie do Sagi o Egilu synu Grima Eysego, [w:] Saga o Egilu, ze staroislandzkiego przeł. A. Załuska-Strömberg, posłowie G. Labuda, Poznań 1974, s. 214-244

Labuda G., Powstania Stowian połabskich u schyłku X wieku, Slavia Occidentalis 18 (1939-1947), s. 153-200

Labuda G., Rozwój metod dziejopisarskich od starożytności do wspótczesności, Część 1: Do schyłku XIX wieku, Poznań-Wrocław 2003

Labuda G., Rozwój metod dziejopisarskich od starożytności do wspótczesności, Część 2: Wiek XX, Poznań 2010

Labuda G., Saga o Styrbjörnie, jarlu Jómsborga ( $z$ dziejów stosunków polsko-szwedzkich $w$ X wieku), Slavia Antiqua 4 (1953), s. 283-337

Labuda G., Slavs in early mediaeval Pomerania and their relations with Scandinavians in the $9^{\text {th }}$ and $10^{\text {th }}$ centuries, [w:] Poland at the XI International Congress of Historical Sciences in Stockholm, Warszawa 1960, s. 61-80

Labuda G., Stowianie, Goci i Hunowie, [w: tegoż, Fragmenty dziejów Stowiańszczyzny Zachodniej, Poznań 1964, s. 22-106

Labuda G., Stowiańszczyzna pierwotna: wybór tekstów, Poznań 1954

Labuda G., Słowiańszczyzna starożytna i wczesnośredniowieczna. Antologia tekstów źródłowych, Poznań 1999

Labuda G., Stowiańszczyzna Zachodnia i Polska w „Pieśni o Rolandzie”, [w:] tegoż, Źródta, sagi i legendy do najdawniejszych dziejów Polski, Warszawa 1960, s. 199-241

Labuda G., Widsith, [w:] tegoż, Źródła, sagi i legendy do najdawniejszych dziejów Polski, Warszawa 1960, s. 153-198

Labuda G., Ziemie polskie i nadbałtyckie w opisie Europy króla Alfreda, [w:] tegoż, Źródta, sagi i legendy do najdawniejszych dziejów Polski, Warszawa 1960, s. 11-90 
Labuda G., Źródła, sagi i legendy do najdawniejszych dziejów Polski, Warszawa 1960 Manteuffel T., Polityka unifikacyjna Chlotara II, Warszawa 1925

Manteuffel T., Stosunki polityczne frankońsko-wtoskie w wieku VI, Kraków 1927

Manteuffel T., Teorja ustroju feodalnego wedtug Consuetudines Feudorum (XIIXIII w.), Warszawa 1930

Michałowski R., Tadeusz Manteuffel jako badacz dziejów Franków, Przegląd Historyczny 86 (1995), z. 3-4, s. 313-318

Moszczeńska W., Arystokracja w państwie Franków za dynastji Merowingów, Warszawa 1932

Naukowe dzieło Gerarda Labudy, red. J. Dobosz, Poznań 2006

Serejski M.H., Idea Imperium Romanum w Galii Merowińskiej w VI wieku, Przegląd Historyczny 25 (1925), s. 261-314

Strzelczyk J., Gerard Labuda jako historyk wczesnej Stowiańszczyzny i kontaktów polsko-niemieckich, [w:] Naukowe dzieło Gerarda Labudy, red. J. Dobosz, Poznań 2006, s. 95-110

Strzelczyk J., Gerard Labuda jako historyk wczesnej Stowiańszczyzny i stosunków słowiansko-niemieckich, Acta Cassubiana 19 (2017), s. 19-32

Szczerba A., Powołanie Kierownictwa Badań nad Początkami Państwa Polskiego, Przegląd Archeologiczny 65 (2017), s. 13-18

Źródła skandynawskie i anglosaskie do dziejów Stowiańszczyzny, wyd. G. Labuda, Warszawa 1961 